\title{
プレストレストコンクリート橋梁特に鉄道橋における プレストレッシングの管理に関する研究
}

\section{STATISTIC CONTROL OF PRESTRESSING ON THE PRESTRESSED CONCRETE BRIDGE}

$\begin{array}{llr}\text { 野 } & \text { 口 } & \text { 功* } \\ \text { By } & \text { Isao } & \text { Noguchi }\end{array}$

\section{1. 緒論}

ある製品をつくる場合，その製品が何であろうと製品 に期待したとおりの性能あるいは品質を持たせようとす る努力が行なわれる。しかし，われわれの作る製品は 100 個作れば，100 個とも多少とも異なった性能あるい は品質をそなえることはさけられず，まったく同一の製 品を作ることはできない。製造する製品にばらつきはさ けられないからといって，製品のばらつきを放任してお けば，てれを用いて所要の性能を有する部材を作るため に大きな安全率を考皇なければならなくなり，したがっ て製品のコストが非常に高くなる。逆に安全率を考えな ければ，信頼性の小さい部材しか作ることができないて とになる。プレストレストコンクリートにおいて,コン クリートの品質の管理, P C 鋼材の品質管理というもの は信頼性の高いP C 部材を作って行くうえに非常に大切 な事がらである。しかし，プレストレストコンクリー トにおいては，十分に品質管理された材料を組み合わせ るでけでは信頼性の高いP C 部材を製作することはでき ない。なぜならば,プレストレストコンクリートにおい ては, 所定のプレストレスが与えられて,はじめて所要 の品質を備えた整品となるからである。P C 部材に要求 される品質, すなわち, 所要の強度と耐久性を得るため にプレストレスの大きさを管理することは，コンクリー トの品質管理, P C 鋼材の品質管理と同等, あるいはそ れ以上に大切な事がらであろう。にもかかわらず，てれ までプレストレスの大きさの管理については, 国内はも とより外国においても，ほとんど深い関心がはらわれて いなかった。内外の研究としては, フランスの Baret 氏 の研究報告があるだけである。氏の報告においても，P C鋼材の伸びから推定される引張力之荷重計の読みから 推定される引張力の間に生じる誤差について,一つの現 場におけるデータをあげて概念的な説明が行なわれてい る程度である。鉄道橋においては, 設計荷重に近い活荷 重が一日数 10 回ないし百数 10 回のくり返し回数で載荷 されるので, P C 部材に設計で考えたとおりのプレスト レスが与えられなかった場合, P C部材の安全性, 特に

* 正員 国鉄構造物設計事務所
疲労に対する安全性について他の種類の構造物にくらべ て，はるかに大きい影響があると考えられる。また，わ が国における P C 鉄道橋の工事量は諸外国の鉄道におけ る工事量にくらべて非常に多いのである。正確なプレス トレッシングの作業を多くの現場において実施して行く ためには，プレストレッシングの管理を実用的な方法で 確立することが要求される。

ての研究は東京大学 国分正㸝教授より, 終始で慇篤 なで指導を賜わりながら，その一部を吉田研究奖励金に よって行なったものである。研究の実施にあたっては， 国鉄構造物設計事務所 友永前所長, 故川口元次長, 河 野現所長はじめ各位ので指導をいただき，研究資料の収 集, 収集資料の取りまとめについては終始, 幹線総局土 木部設計課の斉藤氏ので協力をいただいた。

その他の現場における管理の実施ならびにデータの収 集については, 構造物設計事務所 小池技師ほか田村, 椎田, 小須田, 高藤の各氏ならびに現場担当者ので援助 を得たものである。こてに謹んで厚くお礼申し上げる。

\section{2. プレストレッシングの重要性と，管理に関す る従来の実状}

プレストレストコンクリートは荷重によって生ずる 応力と逆の応力をあらかじめ与えるてとを使命としてい るので, この応力の与方いかんによっては, 期待した だけの部材の強度を有することができない結果となる。 しかし，与えられたプレストレスは目で見て検査するて ともできないし，また簡単にプレストレスを測定できる ような機器も存在していない。このように部材の強度に 非常に大きな影響を与えるにもかかわらず，その結果を 知り得ないということは, 部材の信頼性という面から非 常に大きな問題である。しかしながら，てれまでプレス トレッシングの管理に対して, 技術者の関心は非常に薄 かったといわざるを得ない。乙の責任を単に現場技術者 にだけ負わせることはできない。それは現場技術者の作 業のよりどてろとなる施工基準にも，ほとんど具体的な 事項について記されたものはなく，プレストレッシング の問題点にもふれず, 単に "設計で考えられたプレスト レスが与えられるようにしなければならない”。という 
通りいっぺんの表現で片づけられていたからでもある。 もちろんこれは，わが国だけのことではなく，外国で制 定されている施工基準にもほとんど明確な管理方法とい うものは，規定されていない。あるいは規定されていて も，プレストレッシングの䛊差というものを十分に把握 したうえでの規定であるとは考えられない。

二,三の外国の施工基準の例をあげてみると, A.C.I. -A.S. C.E. Joint Committe により 1957 年に制定され た Tentative Recommendations for Prestressed Concrete には, “ポストテンション方式部材において，伸 びから推定される P C 鋼材の引張力と荷重計から推定さ れる $\mathrm{P} \mathrm{C}$ 鋼材の引張力の間に $5 \%$ の䛊差を生じた場合に は, プレストレッシングの作業を中止し, 誤差の原因が 測定の誤りにも，機械の故障にもよらない場合には責任 技術者に相談しなければならない”，之規定されている。

また，フランス国鉄のプレストレストコンクリート 施工示方書には “荷重計の読 みが 所定の 值に達したの に, 伸びが所定の值に達していない場合には伸びが所定 の值に達するまで荷重計の読みを上げることができる が，5\%を越えてはならない。荷重計の読みを $5 \%$ 上げ ても所定の伸びに達しない場合には, 緊張作業を中止し なければならない。荷重計が所定の值に達する前に伸び が得られた場合には, 荷重計が所定の值に達するまで緊 張を続けること”，と規定されている。

プレストレッシングの祭の許容の誤差について, 具体 的に数字をあげて基準を決めている示方書は外国におい ても少なく，上記の二例ぐらいのものである。

これらの基準に記されているように, 荷重計から推定 される引張力と伸びから推定される引張力の間に $5 \%$ 以 上の差を生じた場合は異常の状態であるという解釈をす ると, 実際にプレストレッシングの作業に立会った者で あれば了解することができるのであるが, 緊張作業を行 なって見ると異常のケーブルだらけという事実にしばし ばそうぐうすることがある。そして測定の誤りでも，機 械の故障でもないのである。つまり測定の䛊りがなく， 機械の故障がなくても, 両方の測定值の間には $5 \%$ 以上 の差を生じることが, かなり高い確率であらわれるので ある。このように $5 \%$ という許容限度は実際的な見地か ら考えるとあまり意味のない值であるということができ る。しかし，この $5 \%$ という值がプレストレッシングの 誤差に直結する值であるとすると部材の安全度という見 地から $5 \%$ 以上の䛊差を許すということはできない。

プレストレッシングの誤差が, 実際にどの程度部材の 安全性に影響を与えるものであるか，一，二の例につい て計算してみることにしよう。

緊張計算には, $\mathrm{P} \mathrm{C}$ 鋼線のヤング係数 $E_{p}=2.10 \times 10^{6}$ $\mathrm{kg} / \mathrm{cm}^{2}, \mathrm{P} \mathrm{C}$ ケーブルの角変化 1 ラジアンあたりの摩擦 損失係数 $\mu=0.3, \mathrm{PC}$ ケーブルの長さ $1 \mathrm{~m}$ あたり摩擦
損失係数 $\lambda=0.004$ の值を使用した。そして実際に: $E_{p}=2.00 \times 10^{6} \mathrm{~kg} / \mathrm{cm}^{2}, \mu=0.45, \lambda=0.006$ で, し亡方 マノメーターの指度が正しい引張力より $5 \%$ 高い值を示 す狂いを生じていたと仮定し，乙れ以外は，実際の状態 が完全に緊張計算の仮定と合致していたものとする。ス パン $15.8 \mathrm{~m}$ および $35.00 \mathrm{~m}, \mathrm{KS}-18$ の鉄道橋の標準 枌について計算してみると, 荷重計の示度によって引き 止め点を決める場合, 緊張計算の仮定と, 実際の状態の 違いによって, 表一1 のような引張力の誤差ならびにプ レストレスの不足を生じる。この程度の誤差は, ほ之ん どおこり得ないような誤差であるとはいえない。

\begin{tabular}{|c|c|c|c|c|}
\hline \multirow[t]{2}{*}{ 表-1 } & \multicolumn{4}{|c|}{$\begin{array}{l}\text { プレストレッシングの誤差が引張悢のコンクリート } \\
\text { の引張応力度にあらわれる影響（スパン } 35 \mathrm{~m} \text { およ } \\
\text { び } 15.8 \mathrm{~m} \text { の鉄道橋用標準枌） }\end{array}$} \\
\hline & & & 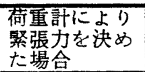 & $\begin{array}{l}\text { 伸ひにより緊 } \\
\text { 彭力を決如た } \\
\text { 場合 }\end{array}$ \\
\hline \multirow{2}{*}{\multicolumn{2}{|c|}{$\begin{array}{l}\text { 道入直後のプレストレ } \\
\text { スカの詿差 }\end{array}$}} & スパン $35 \mathrm{~m}$ & $-12.2 \%$ & $-7.1 \%$ \\
\hline & & スパン $15.8 \mathrm{~m}$ & $-10.6 \%$ & $-6.7 \%$ \\
\hline \multirow{2}{*}{\multicolumn{2}{|c|}{ 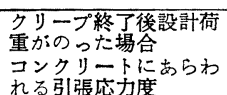 }} & スパン $35 \mathrm{~m}$ & $24.7 \mathrm{~kg} / \mathrm{cm}^{2}$ & $13.7 \mathrm{~kg} / \mathrm{cm}^{2}$ \\
\hline & & スパン $15.8 \mathrm{~m}$ & $17.5 \mathrm{~kg} / \mathrm{cm}^{2}$ & $10.5 \mathrm{~kg} / \mathrm{cm}^{2}$ \\
\hline
\end{tabular}

設計荷重が作用したとき，表一1 に示すような引張灾 力を生じることがどの程度の重大事であるかということ になるが，パーシャル プレストレッシングとして部祆 を設計する場合, コンクリートに許される許容引張応力 は, 土木学会 P C 指針によると, $\sigma_{28}=400 \mathrm{~kg} / \mathrm{cm}^{2}$ のコ ンクリートを使用し, 引張側が断面の下側にある場合 $25 \mathrm{~kg} / \mathrm{cm}^{2}$, 引張側が断面の上側にある場合 $15 \mathrm{~kg} / \mathrm{cm}^{2}$ ご ある。しかも，乙の場合，コンクリートの受ける引張力 亿肩代わりし得るだけの鉄筋を配置しなければならない のである。

鉄道橋においては，てれまでパーシャル プレストレ ッシングの設計を行なわず，フル プレストレッシング の設計ばかりであったが，仮りにパーシャル プレスト レッシングの設計を許すものとすると図一1 に示すよう に引張力に対して鉄筋を配置しなければならない。こし て計算上必要な鉄筋量は鉄筋の許容引張応力を 1400 $\mathrm{kg} / \mathrm{cm}^{2}$ とすると荷重計により緊張力を決めた場合, ス パン $35 \mathrm{~m}$ において1主杵あたり $18.5 \mathrm{~cm}^{2}$ の断面積, スパン $15.8 \mathrm{~m}$ において，1主桁あたり $7.4 \mathrm{~cm}^{2}$ の断面 積となる。

また，伸びにより緊張力を決めた場合，スパン $35 \mathrm{~m}$ において1主桁あたり $6.5 \mathrm{~cm}^{2}$ の断面積, スパン 15.8 $\mathrm{m}$ において1主析あたり $2.9 \mathrm{~cm}^{2}$ の断面積となる。

フル プレストレッシングの設計とパーシャル プレス トレッシングの設計が等しい安全度を有するものである と仮定すると，フル プレストレッシングの設計におい てプレストレスが不足し，表一1および図一1に示すよ うな引張応力が生ずるととは，上記のような鉄筋が不足 するのと同等の安全性の低下があるものと考えるてとが 
図一1 プレストレスの不足によりコンクリートに生ずる引張応力 スパン $35.0 \mathrm{~m}(4 \doteq 1)$

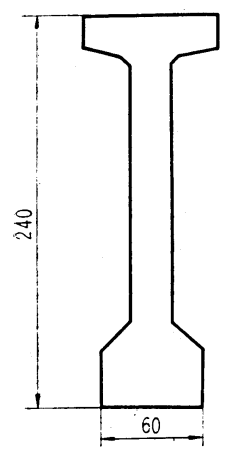

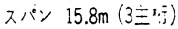

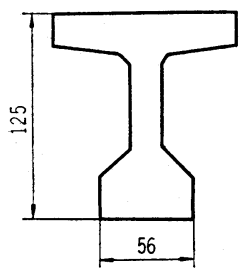

きる。

通常の土木工事においては，あまり大きな関心がはら われない程度の誤差が，てのように P C 部材の安全性に 大きな影整をもたらすのである。

プレストレッシングの誤差が数 \% 程度あると部材の 安全性に対する影整を無視するととができなくなるのに 対し，P C 鋼材の伸びと荷重計の読みから推定される引 張力を $5 \%$ 以内の差におさめることは一般的に不可能 であるという事実を考えた場合，設計上，つぎのような 点を考えて設計で期待した安全度を確保する道が残され ている。すなわち,

（1）計算上必要なプレストレスに対し余分のプレス トレスを与え, 部材引張部に 対し王縮応力の 余裕を残 す。

（2）設計で考えたP C 鋼材の引張応力より常に高い 引張応力が与えられるよう, 施工の際に引き止め点を决 定する。

（3）プレストレスが不足した場合にもパーシャル プレストレッシングの部材としてもつように引張鉄筋を 配置する。

おてり得る謓差を想定して，上記のような手段を講ず ることは必要なととであるが, 従来は, おとり得る誤差 の大きさも明確にされず，しかも上記 3 項のような設 計，施工上の考慮もあまりはらわれなかったというのか 実状である。また，もし上記のような処置をとるとすれ ば，それだけP C 部材の経斉性の損失に影整があらわれ てくる。
従来，与えられたプレストレスの大きさを検査す る方法としてプレストレスによる P C 部材の反り量 を測定することがしばしば行なわれている。理論的 には，反り量を測定することによって与えられたプ レストレスを検査することができるのであるが，実 際には所要の精度でプレストレスを検査する手段と しては不十分である。

なぜならば，先にも述べたようにプレストレスの 大きさは数 \% 程度以下の精度で与えなければなら ないのに対し, 反り量測定では数％の精度でプレ ストレスの大きさを推定することは不可能だからで ある。てれは反り量からプレストレスの大きさを推 定するにはコンクリートのヤング係数を仮定しなけ ればならないが, コンクリートのヤング係数を高い 精度で求めることができないからである。

\section{衰一2 反り量の測定結果}

\begin{tabular}{|c|c|c|c|}
\hline 檑梁名 & 枌本 数 & 平均反り $(\mathrm{mm})$ & 变辑係数 $(\%)$ \\
\hline 小 丸 川 & 31 & 22.0 & 9.1 \\
\hline 森 戸 川 & 14 & 17.0 & 8.8 \\
\hline 早 川 & 8 & 19.9 & 5.5 \\
\hline
\end{tabular}

衣一2 は現場においてP C部材の反り量を測定し たデータであるが，同一の P C 部材を製作した場合に反 り量の変動係数は $10 \%$ 程度にも達する場合があり，と れでは数 \% の誤差を検出する役には立たない。また， その前の段階として, 反り量の基準となるプレストレス 導入時のコンクリートのヤング係数の適当なる值を决め るととがほとんど不可能でもある。したがって，反り量 は参考值として知る程度にしか役に立たないということ ができる。

プレストレッシングの実際の作業は現場技術者の監督 のもとに行なわれるが, ジャッキの操作，伸びの測定な どは作業員によって行なわれるのが普通である。このた め測定值に誤りが入る可能性も少なくなく，㸷張記録に 全面の信頼を置くことができない場合もおてってくる。 この欠点を防ぐためには，ジャッキの圧力と伸びの量が 自動記録される装置を使用することができ，外国におい ては特殊な工法において一部で実用されている。てれも よい管理を行なうための一つの要素ではあるが, 実際に 緊張されたデータが誤りなく記録として残されるという だけであってプレストレッシングの呮差を管理するとい う面からは，決しててれだけやれば十分であるといい得 るものではない。自動記録装置を使用しなくても管理の 記録から作業員の誤りを容易に発見できる方法を講ずる ととはさして困難なととではないと考えられる。

以上, プレストレッシングの管理の重要性とそのむず かしさ，さらに現在行なわれている方法が不本意なもの であるととを述べたが，てれらを要約してプレストレッ シングの管理にあたって必要な問題点を提起するとつぎ 
のようになる。

（1）プレストレッシング作業中の作業員による測定 の誤りをただちに発見でき，修正し得る方法を考えるて 之。

（2）荷重計のキャリブレーション，摩擦測定を行な うことを規定するばかりでなく，荷重計の示度の狂い， 摩擦係数の変動がすみやかに発見できる方法を考えるこ 之。

（3）プレストレッシングの際の誤差を明らかにした うえで, 設計で考えた部材の安全性を確保するためのプ レストレッシングの管理の方法，あるいは設計施工上考 えなければならない処置を明らかにするとと。

\section{P C 鉄道橋梁工事, 13 現場におけるプレス トレッシング管理の調查結果}

\section{(1) 概 要}

土木学会論文集第 76 号「小丸川P C 鉄道橋の架替元 工事ならびに関連して行なった実験的研究報告」におい て, 小丸川橋梁工事における 76 号の P Cヶーブルのプ レストレッシングの結果から，プレストレッシングにお いておてる誤差を推定した。その結果，プレストレッシ ングにおいて，P C 鋼材の伸びから設計断面における引 張力を推定する場合にも，荷重計の読みから引張力を推 定する場合にも，各種のばらつきの原因によって 表一3 に示すように 3 5 \% 程度の標準偏差のばらつきはさけ られないとと，したがって，伸びから推定される引張力 之荷重計の読みから推定される引張力の間にも 3 5\% の標準偏差の ばらつき（図一2）の差を生じることがさ けられないととが明らかにされた。そして，てのさけら れない偶然誤差を許しながら，正しいプレストレッシン グを行なって行くためには，PCヶ ーブルを組にわけ，各組でとに伸び から推定される引張力と荷重計から 推定される引張力の差の平均值をと り，偶然誤差によるばらつきの影響 を小さくしておいて，故障原因によ る差を鋭敏に検出して作業を改善し て行く方法が非常に実用的であるこ とを示した。図一3において，個々 の $\mathrm{P}$ Cヶーブルについての(1)〜(2)の 值は非常に大きくばらついており， このばらつきの中から故障原因を見 出すととは困難であるが, 各 $\mathrm{PC}$ 桁 に含まれる PCヶーブルでとに平均 值をとってみると，ばらつきは非常 に小さくなり, No. 16 以降の标のプ レストレッシングに故障原因が介入 して来ているととが明りょうにあら
䒾一3 測定方法とばらつきの大きさ

\begin{tabular}{|c|c|c|c|}
\hline 測定内容 & ばらつきの原因 & $\begin{array}{l}\text { ばらつきの } \\
\text { 大きさ }\end{array}$ & \begin{tabular}{|l} 
一方に偏寸 \\
万鮕差
\end{tabular} \\
\hline \multirow[t]{2}{*}{$\begin{array}{l}\text { 伸びにより測 } \\
\text { 定した場合 }\end{array}$} & 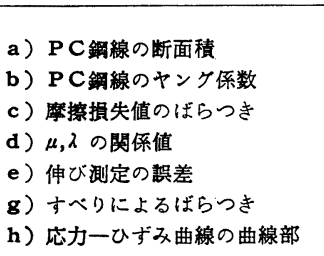 & $\mid \begin{array}{c}\text { (標準偏差) } \\
0.6 \% \\
1.7 \\
1.5 \sim 2.5 \\
0 \sim 1.5 \\
1 \\
0 \sim 1.5 \\
0.35\end{array}$ & 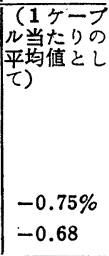 \\
\hline & total & $2.5 \sim 4.5$ & -1.43 \\
\hline \multirow[t]{2}{*}{$\begin{array}{l}\text { 荷重計により } \\
\text { 測定した場合 }\end{array}$} & 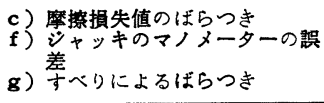 & $\begin{array}{c}3 \sim 5 \\
2 \\
0 \sim 1.5\end{array}$ & -0.75 \\
\hline & total & $3.6 \sim 5.6$ & -0.75 \\
\hline $\begin{array}{l}\text { 荷重計から求 } \\
\text { めた㗨張力と } \\
\text { 伸びから求め } \\
\text { た㗨張力の差 } \\
\text { を生ずる原因 }\end{array}$ & 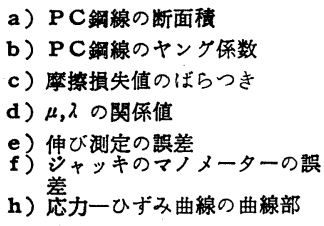 & $\begin{array}{c}0.6 \\
1.7 \\
1.5 \sim 2.5 \\
0 \sim 1.5 \\
1 \\
2 \\
0.35\end{array}$ & \\
\hline を生ずる原因 & total & $3.2 \sim 4.8$ & -0.68 \\
\hline \multirow{2}{*}{$\begin{array}{l}\text { 両者の読みの } \\
\text { 差の原因とな } \\
\text { らない摆差 }\end{array}$} & $\begin{array}{l}\text { c）摩摖損失值のばらつき } \\
\text { g)すべによばらつき }\end{array}$ & $\begin{array}{c}1.5 \sim 2.5 \\
0 \sim 1.5\end{array}$ & -0.75 \\
\hline & total & $1.5 \sim 2.9$ & $-0.75 \%$ \\
\hline
\end{tabular}

われている。しかし，細かい点に関しては残された問題 も少なくないので, さらに多くの工事現場において調查 を行なう必要がある。特に P C ケーブルの長さとか, 配 置の形状，あるいはケーブルの種類に無関係に一定のば らつきの值を考えてよいものかどうかという問題が残さ れている。また，伸びの測定值と荷重計の読みから推定 される引張力との差は確率的にあらわれる誤差であると し，われわれが実用的に整備し得る範囲内にわいて P C 図一2 圧力㖕の読みと測定㯈との間の差

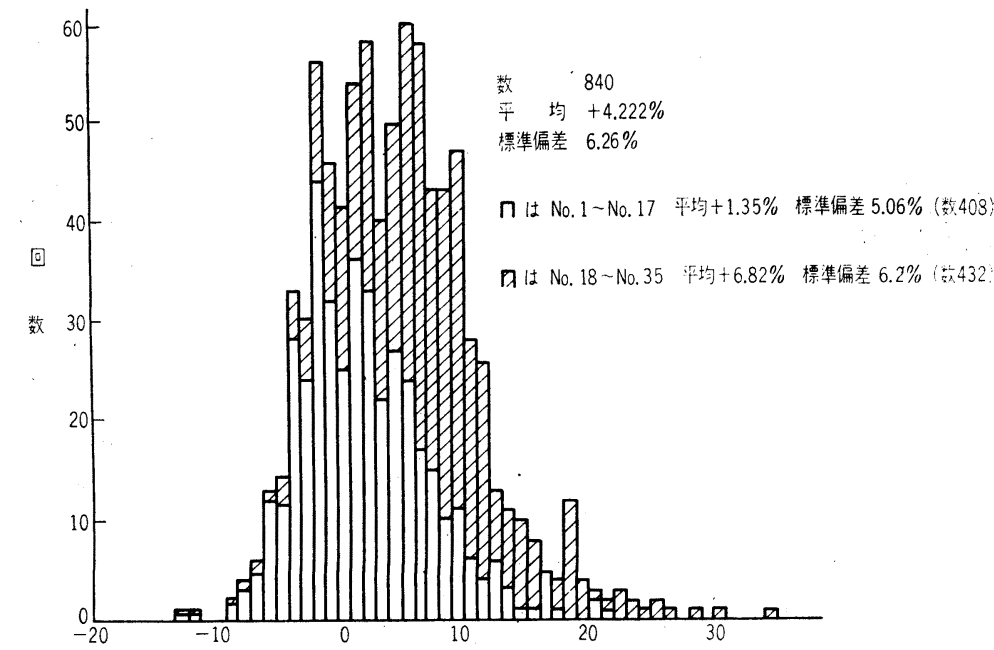

注）十は压力計の読みを計算の値に一值させたとき計算ののび量より実除ののひ

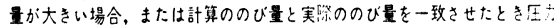
計の指度か計算による指度より低い場合。 
図一3 各 P C ケーブルの緊張データ

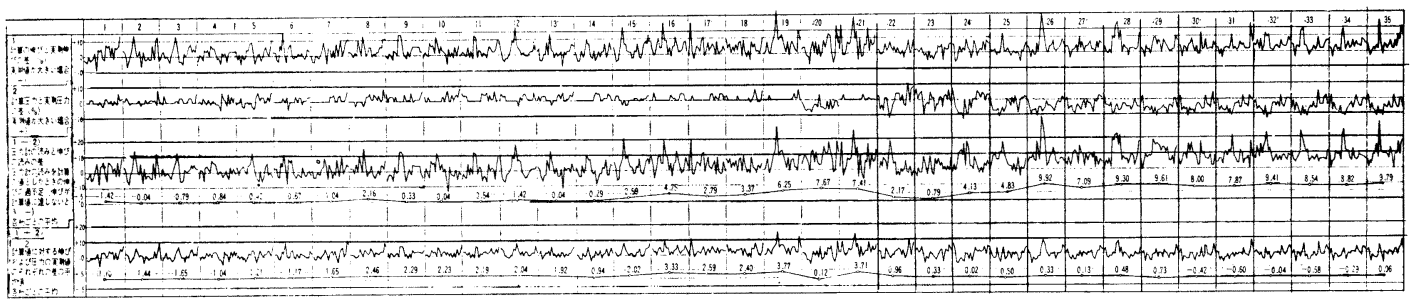

ケーブルの組の中の数を多くとればとるほど, 再者の差 の平均值は 0 に近づくと考えているが，実際には，ある 程度の荷重計の狂い，P C 銅材のヤング係数の测定値と 真の值との差, 計算上の近似などというものを完全に排 除することはできないので，乙れらの影響を管理の上に どのように反映させるかの問題が残されている。てれら の問題を解決するためには統計的な管理方法を現場に適 用し，実用上の問題点を明らかにしなければならない。

以下にこれらの問題について, 13 現場におけるおよ そ 3000 本のPCケーブルの緊涱結果について検討を加 えることにしよう。

（2）プレストレッシングの管理データに対する検討 a) 緊張計算過程に対する檢討 主として国鉄のP C 工事の現場 13 力所において合計約 3000 本のPCケー ブルの緊掁データについて，伸びから推定される引張力 と荷重計の読みから推定される引張力の間の差について

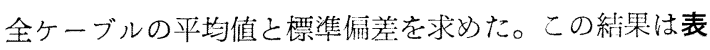
-4 に一覧表にしてある。

表一4 現場における調査結果から得られた伸びと荷重計 から推定される引張力の差

\begin{tabular}{|c|c|c|c|c|}
\hline \multirow{2}{*}{ 晛 場 名 } & \multirow{2}{*}{$\begin{array}{r}ケ ー フ ゚ ~ \\
ル \text { 本数 }\end{array} \mid$} & \multirow{2}{*}{ ケーブルの種類 } & \multicolumn{2}{|c|}{$\begin{array}{l}\text { 伸びから推定される引 } \\
\text { 張力之荷重計から推定 } \\
\text { される引張力の差 * }\end{array}$} \\
\hline & & & \begin{tabular}{|c|} 
全ケープル \\
の平均値 \\
$(\%)$
\end{tabular} & $\begin{array}{l}\text { 標準偏差 } \\
(\%)\end{array}$ \\
\hline 根 岸 線 & 100 & フレシネー $12 \times \phi 7$ & +2.66 & 3.94 \\
\hline " & 360 & " & +1.62 & 4.62 \\
\hline $\mathrm{C}$ & 300 & " & +1.70 & 4.10 \\
\hline $\mathrm{D}$ & 395 & " & +0.89 & 4.30 \\
\hline 鬼怒川(連続桁) & 203 & フレンホー $12 \times \phi 12.4$ & +4.12 & 8.04 \\
\hline 鬼怒川(単純枌) & 159 & フレンネー $12 \times \phi 7$ & -0.73 & 4.19 \\
\hline 根川 & 40 & " & +2.38 & 2.48 \\
\hline 熟の巣 & 70 & ディピィダーグ $\phi 27$ & -3.20 & 4.14 \\
\hline 永 野 田 & 72 & フレシネー $12 \times \phi 7$ & +1.99 & 3.68 \\
\hline 小丸川（前 半） & 408 & " & +1.35 & 5.06 \\
\hline " (後 半) & 432 & $"$ & +6.82 & 6.20 \\
\hline 美 幌 川 & 160 & " & +3.20 & 3.62 \\
\hline 丸子川 & 160 & $"$ & +3.20 & 3.81 \\
\hline 井出川 & 120 & " & +1.70 & 4.24 \\
\hline 首都公団 4 号線 & 144 & B.B.R.V. $36 \sim 44 \times \phi 6$ & -0.85 & 2.12 \\
\hline
\end{tabular}

*（十）符号は, 伸びから推定される引張力が大きい場合、すなわち荷 重計の読みが計算上の值に達したときに，伸びの值が計算值を越えてい る場合，(一) 符号はその逆さ示方。

この表の值からつぎのことについて検討を加えて見よ う。

(1) 両者の測定值の差の平均值について; 理想的な状 態において計算され，施工された場合には多くのケーブ ルについて求められた二つの測定值の差の平均值という
ものは 0 にならなければならないものである。しかし， 伸びから推定される引張力と荷重尌から推定される引張 力の間の差の平均值は 表一4に示すように, 荷重計の狂 っていたてとが明らかになった小丸川 (後半) と, P C 鋼材のヤング係数に修正を施した鷲の巣川を除くと両者 から推定される引張力の差は $-0.73 \sim+4.12 \%$ となり， ほとんどの場合, 伸びから推定される引张力が高くなっ ている。いいかえれば，伸びが計算值より多目にでる傾 向を示しているということがいえる。

(2) 両者の测定值の差のばらつきについて; 土木学会 論文集 76 号に発表した小丸川橋梁において, 伸びから 推定される引張力と荷重計か推定される引張力の差のば らつきは標準偏差にして 3〜5\%程度であることを論じ た。この結果, 一般的に偶然誤差の標準偏差について 5 \%という值を洘えれば実用的であると推定されたのであ る。その後，国鉄の 13 の工事現場と首都公団の 1 現場 において標準偏差を求めたとてろ, 表一4 に示すような 值となった。鬼怒川連続枌において $8.04 \%$, 首都公団 4 号線連続析において $2.12 \%$ という特異な值を示して いるほかは大体 3〜6\%の範囲にある。

したがって，偶然䛊差によるばらつきの標準偏差を一 般的に $5 \%$ とすることは十分に実用的な仮定であるとい うことができる。また，非常に大きな現場においては 5 \%の標準偏差にとらわれず，その現場で得られたデー タからその現場における母集団の標準偏差の推定值を計 算し，乙の值を基礎にして管理限界を計算しなおすとと もできるのである。

b）管理図の上にあらわれた判定に対する検討 表一 4 に示した現場のうち比較的良好な管理が行なわれたと 思われる 5 現場における管理図を検討してみることにす る。

5 現場におけるプレストレッシングの管理図は，図一 3 ならびに 4 7 に示すとおりである。標準偏差を $5 \%$ とし，2 シグマの管理限界を考え，1組にふくまれる $\mathrm{P}$ Cケーブル $n$ 本の場合 $\pm \frac{2 \sigma}{\sqrt{n}}= \pm \frac{10}{\sqrt{n}} \%$ を採用する と，管理限界をはずれる P C ケーブルならびに組の数は 表一5 のようになる。表一5 によると，PCケーブルに ついては管理限界をはずれる割合は井出川の場合を除い て $5 \%$ 前後の值となり, 管理限界の決め方が 20 回に 1 回の危険率をおかして決めたてととよく一致している。 
図-4 根岸線 C 現場管理図

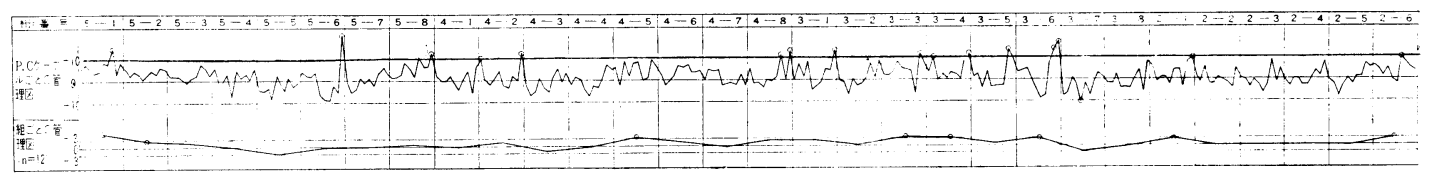

図一5 井出川橋梁管理図

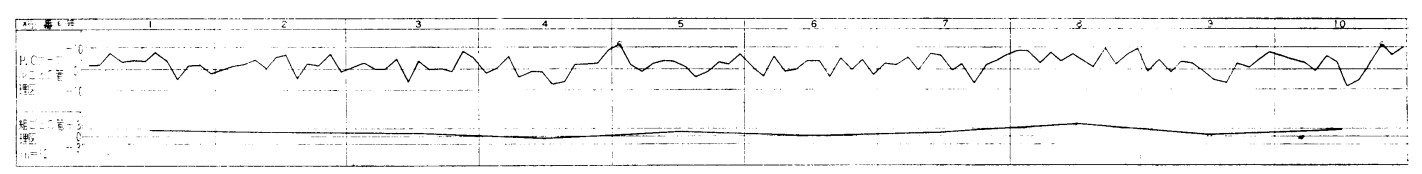

図一6 丸子橋橋梁管理図

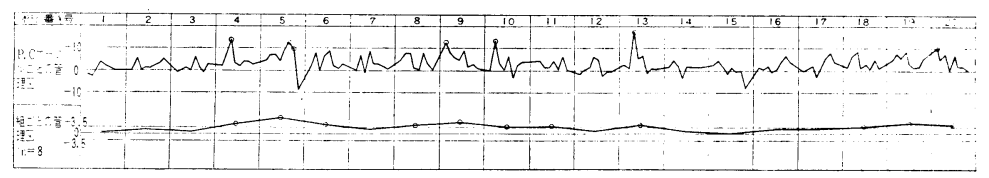

図一7美幌川橋梁管理図

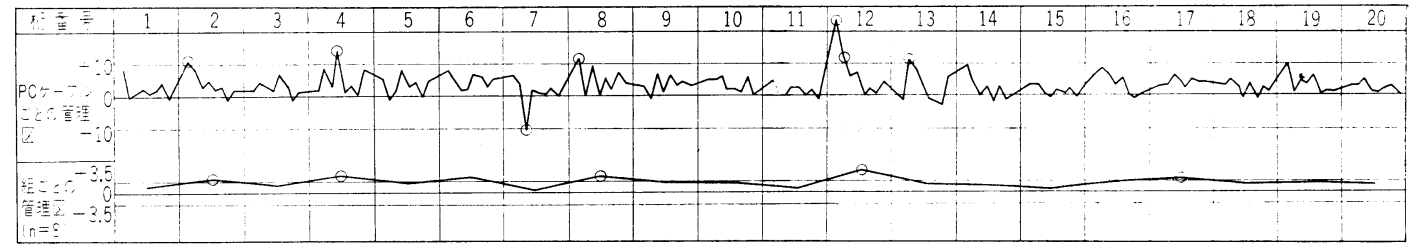

表一5 管理限界の值と限界值をはずれる割合

\begin{tabular}{|c|c|c|c|c|c|c|}
\hline & \multirow{3}{*}{$\left|\begin{array}{l}\text { ケープ } \\
ル \text { 本数 }\end{array}\right|$} & \multirow{3}{*}{$\mid \begin{array}{l}\text { 組の } \\
\text { 数 }\end{array}$} & \multicolumn{4}{|c|}{ 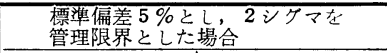 } \\
\hline & & & \multicolumn{2}{|c|}{ ケーブルについて } & \multicolumn{2}{|c|}{ 組について } \\
\hline & & & $\begin{array}{l}\text { 管理限界を } \\
\text { はすすれた数 }\end{array}$ & $\%$ & $\begin{array}{l}\text { 管理限界を } \\
\text { はすれた数 }\end{array}$ & $\%$ \\
\hline 为出 川 & 120 & 10 & $(+) \quad 2(-) 0$ & 1.7 & $(+) 1(-) 0$ & 10.0 \\
\hline 根 岸 線 C & 300 & 30 & $(+) 16(-) 1$ & 5.7 & $(+) 8(-) 0$ & 26.6 \\
\hline 美 幌 川 & 160 & 20 & $(+) 6(-) 1$ & 4.4 & $(+) 6(-) 0$ & 30.0 \\
\hline 丸于 川 & 160 & 20 & $(+) 7(-) 0$ & 4.4 & $(+) 110(-)$ & 55.0 \\
\hline 小 $\begin{array}{c}\text { 小 } \\
\text { No. } 1 \text { No. } 14)\end{array}$ & 336 & 14 & $(+) 15(-) 2$ & 5.1 & $(+) 0(-) 0$ & 0.0 \\
\hline
\end{tabular}

しかし，組についてみると小丸川 (No. 1〜No. 14)を除 いて管理限界をはずれる割合が非常に多くなっており， 特に丸于川においては半数以上の組が管理限界をはずれ ることになる。もし，てれらが異常な状態における緊張 結果であるとすれば当然であるが，てこにあげた現場は 特に緊張管理がよく行なわれたと思われる現場を選んだ のであるから，管理方法の実用性という点から再検討を 行なってみる必要がある。

まず，P Cケーブルを何本かの組にした場合に実際の ばらつきが理論どおりに小さくならないてとは，伸びか ら推定される引張力と荷重計から推定される引張力との 差のばらつきが完全に偶然䛊差だけから成り立っていな いてとを示している。そして，ての理由についてはつぎ のような原因が考えられるのである。

(1) 管理限界のはずれ方が (十) 側にはずれている ものが圧倒的に多い。これは、a)において述べたととと一 致している。このことは伸びから推定される引張力が大
きいととを示すもので $\mathrm{P} \mathrm{C}$ 鋼材の引張試験の結果から求 めたヤング係数より, 実際に緊張する場合のヤング係数 のほうが小さくなるのではないかということが考えられ る。

（2）配置形状の珙なるP C ケーブルを同一母集団と して考えて理論づけを行なったが，実祭には同一母集団 と考えることができず，その影響が管理図の上にあらす れるということが考えられる。

(3) 摩擦測定を全ヶーブルについて行なっておら ず，一般に工事開始前に何本かのケーブルについて行な っているが, われわれが考える以上に摩擦係数の変動が 大きく，ての影響が大きくあらわれていることが考えら れる。

\section{4. 緊張計算において考虑すべき P C ケーブル の見かけのヤング係数}

P C 鋼材の伸びを測定することによって与えられる心゙ き引張力を求めようとする場台には，P C 鋼材のヤング 係数を正確に知っておかなければならない。一般に，使 用する P C 鋼材のヤング係数は P C 鋼材の試験成績表に 付ずいしている応力一ひずみ曲線より求めている。しか し, 多くの緊張作業の結果から, 応力一ひずみ曲線から 求めたヤング係数が真の值ではないと疑われるものがか なりあることが明らかになっだ。というのは, 応力一ご ずみ曲線から求めたヤング係数が鋼の常識をはずれた值 を示し，この值を使用した場台，計算上の伸びと実際の 
伸でが一致しないからである。そてで，一応これまでに 使用した P C 鋼線の試験成績表から求めたヤング係数を 一覧表にまとめてみたところ,つぎの表一6 のようにな った。

表一6 ヤング保数試駼成絞一筧表

\begin{tabular}{|c|c|c|c|c|c|c|c|}
\hline 怘管 & 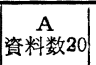 & ${ }_{35}$ & $\begin{array}{ll}\mathrm{C}_{38} & \\
\end{array}$ & $\begin{array}{ll}\mathrm{D}_{23} & \\
x_{2} & \end{array}$ & ${ }_{129}$ & $\begin{array}{ll}F & \\
& 35\end{array}$ & 合 壾 \\
\hline 1.93 & & & 1 & & & & 1 \\
\hline 1.94 & & & & & & & \\
\hline 1.95 & & & 1 & & & & 1 \\
\hline 1.96 & & & & & & & \\
\hline 1.97 & & & & & & & \\
\hline 1.98 & & & & 1 & & & 1 \\
\hline 1.99 & & & & 1 & 2 & & 3 \\
\hline 2.00 & & & & & 4 & & 4 \\
\hline 2.01 & & & 2 & & 7 & & 9 \\
\hline 2.02 & 3 & & 1 & 1 & 9 & & 14 \\
\hline 2.03 & 3 & & 6 & 4 & 15 & & 28 \\
\hline 2.04 & & & 4 & & 21 & & 25 \\
\hline 2.05 & 2 & & 1 & 1 & 18 & & 22 \\
\hline 2.06 & 1 & & 4 & 1 & 16 & & 22 \\
\hline 2.07 & 2 & & 4 & 1 & 13 & & 20 \\
\hline 2.08 & 3 & & 2 & 7 & 9 & & 21 \\
\hline 2.09 & 1 & & 2 & 2 & 5 & 1 & 11 \\
\hline 2.10 & 2 & 4 & & & 2 & 3 & 11 \\
\hline 2.11 & & 7 & 3 & 1 & 2 & 4 & 17 \\
\hline 2.12 & 3 & 11 & 4 & 1 & 2 & 5 & 26 \\
\hline 2.13 & & 3 & & & 2 & 5 & 10 \\
\hline 2.14 & & 7 & & 1 & 1 & 5 & 14 \\
\hline 2.15 & & 2 & 1 & & 1 & 4 & 8 \\
\hline 2.16 & & & & 1 & & 3 & 4 \\
\hline 2.17 & & 1 & 2 & & & 3 & 6 \\
\hline 2.18 & & & & & & 1 & 1 \\
\hline 2.19 & & & & & & 1 & 1 \\
\hline F 均 & 2.066 & 2.120 & 2.066 & 2.070 & 2.050 & 2.130 & 2.075 \\
\hline 変動彩数 & $\mid 1.70 \%$ & $1.63 \%$ & $5.10 \%$ & $4.20 \%$ & $3.24 \%$ & $2.46 \%$ & $4.77 \%$ \\
\hline
\end{tabular}

表一6 亿おいて B およで $\mathrm{F}$ のブロックのヤング係数 は，21000 kg/mm² 越えているが，てれが材料の性質 によっているものか，あるいは測定のためなのかが問題 である。そこで，同一コイルのP C 鋼材のヤング係数が 試験機および解析者によってどのように異なった值を与 えるかを試してみた。

図一8 はその絬果を示すものである。これによると，

图一8 同一コイルの銅線のャング係数

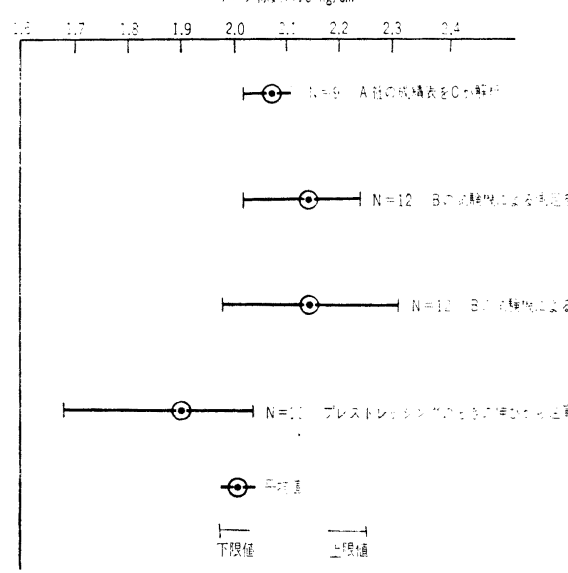

同一コイルから取り出した資料でも試験機によってある いは解析者によって求められるヤング係数の值に大きな 差があることがわかる。A 社の試験による場合の平均值 は $20700 \mathrm{~kg} / \mathrm{mm}^{2}$ であるのに対し，B 社の試験機によ る場合には，平均值が $21400 \mathrm{~kg} / \mathrm{mm}^{2}$ となっている。 プレストレッシングのときの伸びから逆算したヤング係 数は非常に小さいが，てれはあとから論ずるように，プ レストレッシングのときに求められる伸びは鋼線の弾性 変形のみによる伸びだけでなく，他の要素によって伸び が大き目にでてくるためである。

プレストレッシングの際には，かなり長い鋼線につい ての伸びを測定し, 武験機においては $200 \mathrm{~mm}$ 程度の短 いスパンにおいてヤング係数を測定するが，測定スパン が異なるとヤング係数の值がどのようになるかを測定し たものが 図一9 である。ての図は同一チャージから製造 された P C 鋼線についてスパン $10 \mathrm{~m}$ から $100 \mathrm{~m}$ まで の間の長さで, ヤング係数を求めたものであるが，伸び の測定を $10 \mathrm{~m}$ の場合も $100 \mathrm{~m}$ の場合も同一の尺度で 求めたため, スパンが長くなるほど測定精度が高くなり ばらつきが小さくなっているが，各スパンでのヤング係 数の平均值はほとんぞ一定している。

图一9 ヤング係数測定のスパン長とばらつき

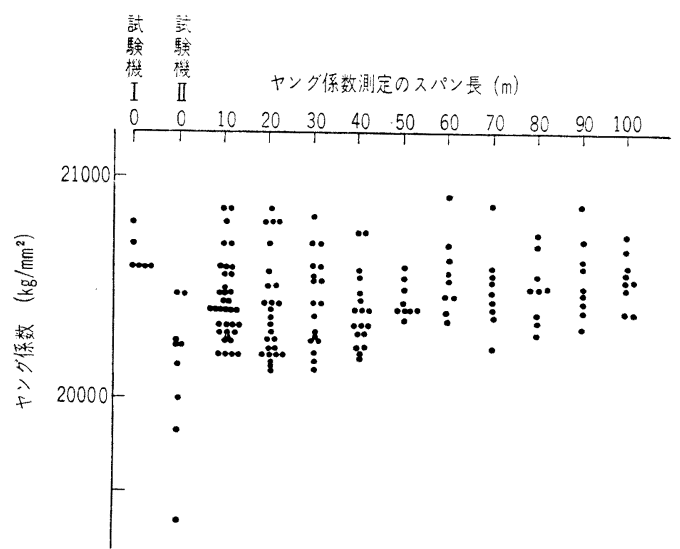

これに対し, 引張試験機から求めた $200 \mathrm{~mm}$ のスパ ンでのヤング係数は明らかに異なった平均值を与えてお り，二つの試験機でもその值は異なっている。

われわれはこれまで試験成績表から求めたヤング係数 を使用して，ブレストレッシングの際における伸びを計 算するのが正しい方法であると考えてきたが，以上の事 がらを総合してみるに試験成績表のヤング係数の值は使 用する P C 鋼材のヤング係数の妥当な值を示しているの ではなく，材料のばらつきによってヤング係数がばらつ くと考えられていたのが，実は試験機あるいは解析者の 誤差をあらわすものであると考えることができるのであ る。そして, 試験成績表より求めだング係数が何であ ろうとも使用する P C 鋼線 のヤング 係数は 20500 $21000 \mathrm{~kg} / \mathrm{mm}^{2}$ の間にあると考光るととができる。そし 
て P C 鋼材自体のヤング係数は試験成績表によるまでも なく, $20500 \mathrm{~kg} / \mathrm{mm}^{2}$ と考元てもせいぜい $1 \%$ 程度の 誤差しか生じないととになる。しかし，プレストレッシ ングにおいて，もっとも必要なととは使用するP C 鋼材 のヤング係数がいくらであるかということではない。必 要なのは伸びの測定結果から設計断面における鋼材の引 張力を正当に評価するための見かけのヤング係数であ る。鋼材のヤング係数之緊張時の鋼材の伸び量に関係す る見かけのヤング係数とは必ずしも一致しない。このて とは図一8 からも明らかである。例えば，表一4につい て調べてみよう。伸びから推定される引張力と荷重計か ら推定される引張力の差の各現場でとについての平均值 を調らべてみると伸びから推定される引張力のほうが大 きくなる場合が非常に多い。乙のととは，プレストレッ シングの際の鋼材の伸びにあらわれてくる見かけのヤン グ係数が一般に鋼材のヤング係数よりいくぶん小さ目の 值になるのではないかというととを示唆している。

てのようなととが考えられるため，いくつかの現場に おいてプレストレッシングの際の P C 鋼材の見かけのヤ ング係数の測定を実施した。1 本1本のPCヶーブルに ついては種々のばらつきの原因が介入するため, 求めら れた見かけのヤング係数のばらつきは大きく個々の值の 信頼性はうすいが, 多くの測定データの平均值について 比較してみると，かなり明らかなととがいえるようであ る。表一7および 図一10は各現場における見かけのヤ ング係数の測定結果である。

\section{表一7 見かけのヤング保数の值}

\begin{tabular}{|c|c|c|c|c|}
\hline 名 & 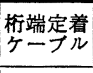 & 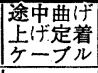 & 全ケーフル & $\begin{array}{l}\text { 参考 } \\
\text { 銿材試験成綪表 }\end{array}$ \\
\hline 根岸線（前半） & $\overline{1.97}$ & $\overline{1.77}$ & $1.90(\bar{N}=3)$ & $2.12(N=35)$ \\
\hline "（後半） & & & & $2.06(N=38)$ \\
\hline 小 丸 川 & $\overline{-}$ & $\overline{1.93}$ & $1.95(\bar{N}=96)$ & $2.07(N=20)$ \\
\hline 森戸川 $(l=24 \mathrm{~m})$ & $\begin{array}{l}1.95 \\
1.98\end{array}$ & $\begin{array}{l}1.76 \\
1.98\end{array}$ & $\begin{array}{l}1.90(N=10) \\
1.98(N=14)\end{array}$ & \multirow{2}{*}{$2.07(N=23)$} \\
\hline " $\quad(l=25 \mathrm{~m})$ & $\begin{array}{l}1.88 \\
1.93\end{array}$ & $\begin{array}{l}1.92 \\
1.96\end{array}$ & $\begin{array}{l}1.90(N=12) \\
1.94(N=13)\end{array}$ & \\
\hline 白 糸 川 & $\begin{array}{l}2.03 \\
2.06\end{array}$ & $\begin{array}{l}1.99 \\
2.03\end{array}$ & $\begin{array}{l}2.01(N=14) \\
2.05(N=14)\end{array}$ & $2.05(N=2)$ \\
\hline 上段のみの平均 & 1.95 & 1.91 & $1.94(N=36)$ & \\
\hline 全 平 均 & 7.97 & 1.94 & $1.95(N=176)$ & \\
\hline
\end{tabular}

注）a）上段の数值は：摩擦誠榆の際に求めた見かけのヤンク係数

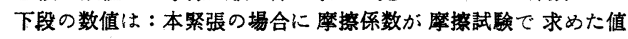
と同じと考えて迹算した見かけのヤンク係数

b) $N$ : 試材数

表一7および 図一10 からいえるととは，

1) 見かけのヤング係数は P C 鋼材のヤング係数より $5 \%$ 程度小さい $1.95 \times 10^{6} \mathrm{~kg} / \mathrm{cm}^{2}$ 程度になるが, 現場 によってかなり大きなばらつきがある。
図一10 見かけのヤング保数のばらつき

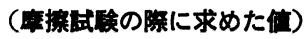
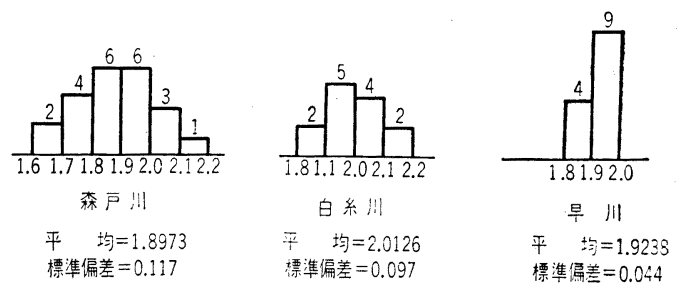

2）二つの測定方法で求めた見かけのヤング係数の值 は必ずしも一致していないが，全体的にほぼ一致した見 かけのヤング係数となっている。てれは各現場における 測定值が比較的少ないためであると考元られる。

3） P C桁の端部で定着されているPCケーブルと途 中で曲げ上げられているケーブルを区別してみた。ての 結果, 途中曲げ上げのP C ケーブルのほうが多少見かけ のヤング係数が小さくなる傾向にある。

結局，伸び測定の際の見かけのヤング係数は P C 鋼材 のヤング係数より小さくなるととは明らかであるという ことができる。また，見かけのヤング係数はケーブルの 配置形状によっても影響されるであろうてとが推定され る。ての点については根岸線および小丸川橋梁において 各形状のケーブルでとにわけた緊張データからうかがう てとができる。ケーブルの配置形状を示す尺度としてケ ーブルの単位長さあたりの曲げ上げ角度をとり，見かけ のヤング係数を示す尺度として伸びから推定した引張力 之荷重計から推定した引張力の差の平均值 (ての值は各 配置形状の $\mathrm{P} C$ 鋼材の見かけのヤング係数が, 繁張計算 に採用した P C 鋼材のヤング係数より, 平均的に何\%低 くなるかを示す) をとり，てれらの関係を求めると図一 11 のようになる。ての図によると,ケーブル $1 \mathrm{~m}$ あた りの曲げ上げ角度が 0.04 ラジアン程度以下の場合 (て れは一般に端部定着のケーブルである）には両者の間に 明確な関係は認められないが, 0.04 以上になると曲げ 上げ角度が大きいほど, 見かけのヤング係数の低下が大 きくなっている。

\section{图一11 見かけのヤング保数とケーブル配国形状との閏係}

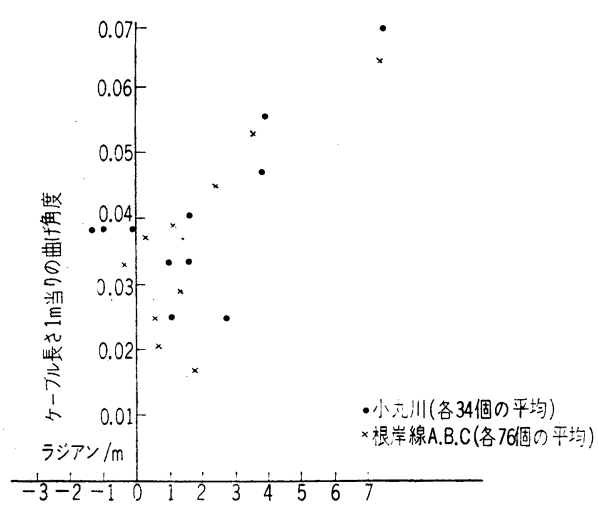


このように見かけのヤング係数が小さくなる原因とし ては，つぎのような理由が考えられる。

(1) P C 鋼材が弯曲して配置されると曲げによる縁 ひずみが加算されるため，応力一ひずみ曲線における比 例限界が低くなり，この影響が伸びにあらわれる。

(2) シース内におけるPCケーブルの位置が緊張に よって鉛直方向に移動する。

（3）一般に测定する P C 鋼材の伸び量は P C 鋼材が 部材端部から报け出す量を測定しているが， P C 鋼材の 真の伸び量は抜け出し量から部材の短縮量を引いたもの で，多少伸びが大き目にでてくる。すなわち，見かけの ヤング係数が低下する傾向を示す。

(1) について；小丸川橋梁における緊張結果を使用し て, 応力ーひすずみ曲線の曲線部分を考慮して伸びの計算 を行なうと小丸川橋梁におけるように端部で非常に高い 緊張力を与えたような場合には, 曲げ上げ角度が大き く, 長さの短い P Cケーブルにおいて, $1.5 \%$ 程度のヤ ング係数の低下を生じるが，普通の場合にはほとんど影 響ないものと見てもよいであろう。

（2）について; 伸びの測定の原点は, 普通 P C 鋼線に $20 \mathrm{~kg} / \mathrm{mm}^{2}$ 程度の引張力を与えたところでとる。このた めシース内におけるPCケーブルのゆるみの影響などは なくなるはずであるが, 緊張力を増して行くにつれて $\mathrm{P}$ $\mathrm{C}$ 鋼線がセンタースパイラルの円周に沿って上方に移 動したり，あるいはセンタースパイラルが変形したり することが考えられる。すなわち, 図一12 のように $\mathrm{P}$ Cヶーブルが移動するため, 見かけ上の伸びが大きくな

図一12 船張による P C ケーブルの移動

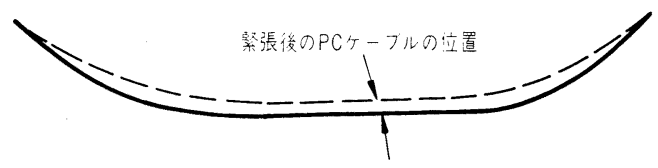

はじめのPCケープルの位置

る。緊張中に P Cケーブルが $1 \mathrm{~cm}$ 上方に移動するもの として, 小丸川橋梁の $\mathrm{PC}$ 析の No. 1, No. 5 , No. 11 ケーブルについて見かけ上の伸びの増加量を計算してみ ると表一8のような值となる。現実にP C ケーブルが緊

表一8 ケーブルの鉛直方向移動におよぼす伸びの增加量 （ケーブル重心が $1 \mathrm{~cm}$ 移動する場合）

\begin{tabular}{c|c|c|c|c}
\hline ケープ番号 & $\begin{array}{c}\text { 長 さ } \\
(\mathrm{m})\end{array}$ & $\begin{array}{c}\text { 曲代上け角度 } \\
(\mathrm{rad})\end{array}$ & $\begin{array}{c}\text { 伸びの增加量 } \\
(\mathrm{mm})\end{array}$ & $\begin{array}{c}\text { 伸びの増加率 } \\
(\%)\end{array}$ \\
\hline No. 1 & 13.0 & 0.421 & 2.6 & 3.7 \\
No. 5 & 23.5 & 0.421 & 2.6 & 2.2 \\
No. 11 & 23.1 & 0.283 & 1.75 & 1.5 \\
\hline
\end{tabular}

張中にシース内においてどの程度の鉛直方向の移動を 行なうかを測定してみた。測定を行なったのは, 図一16 に示すスパン $19 \mathrm{~m} \mathrm{KS}-18$ の標準P C桁の No. 5 ケー ブルである。 P Cケーブルの中央と中央から $8.315 \mathrm{~m}$ の 点に観測穴をあけ緊胀中のP C ケーブルの移動を実測し
たのである。その結果, 圧力 $50 \mathrm{~kg} / \mathrm{cm}^{2}$ から所定の圧力 まで緊張する間の移動量は 図一13 に示すと抢りであっ た。

図一13 PC ケーブルの鉛直移動量

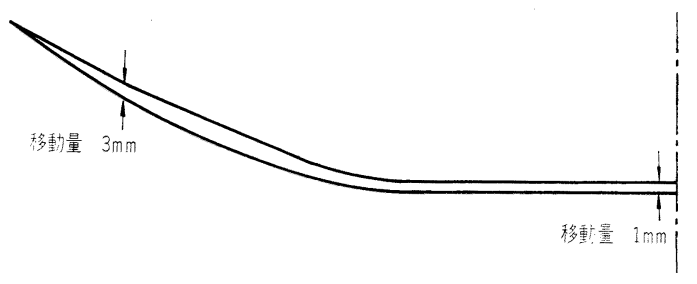

スパン中央で $1 \mathrm{~mm}$, 曲げ上げ途中点で $3 \mathrm{~mm}$ ，そし てての中間がなめらかに移動したものとすると，ての二 つの位置でのPCケーブルはケーブルの半長 $9.80 \mathrm{~m}$ に 対し， $1.1 \mathrm{~mm}$ の長さの差を生ずる。いいかえれば，ケ ーブルが移動することによって, 弾性伸びのほかに片側 で $1.1 \mathrm{~mm}$ の伸びが加えられることになる。この場合， 弾性伸びは $48 \mathrm{~mm}$ であるので, 伸びに対する影響は $2.3 \%$ である。

プレストレッシングの際の P C 鋼材の見かけのヤング 係数が小さくなる理由の一つが，シース内において緊張 力をますとともにP C 鋼材が鉛直方向にわずかでも移動 するためであるという推定が本実験の結果から明らかと なった。乙のことは，PCヶーブルに使用するセンター スパイラルの選定がプレストレッシングの管理の上にお いて大切であることを示唆している。

(3) について; PCケーブルの部材端部からの抜け出 し量之, PCヶーブルの実際の伸び量との差は, 使用方 る P Cケーブルの単位の大きさに関係するもので, 例え ば集中ケーブルを使用するような場合には $10 \%$ 近い差 がでてくるが，このような場合には緊張計算において部 材のちぢみ量を考慮するのが普通である。しかし, フレ シネ一方式あるいはこれに類似の方式のようにPCヶー ブルの単位が比較的小さくて，1本の P C部材に 10 本 程度以上の P Cケーブルを使用するような場合には，一 般に抜け出し量をもってPCケーブルの伸び量と考える のが普通である。

小丸川橋梁 $\mathrm{P} \mathrm{C}$ 桁の場合において, 抜け出し量を伸び 量と考えたことによる P C 鋼材の見かけのヤンダ係数の 低下率は $0.5 \%$ 程度以下である。

(1), (2),(3) の理由によって P C 鋼材のヤング係数が 見かけ上低下するということになる。長さが短く，曲げ 角度の大きい途中定着の P C ケーブルの見かけ上のヤン グ係数の低下率が大きくなる傾向があり，乙れは 表一7 の見かけのヤング係数の実測のデータおよび 図一11の 結果と一致している。

ヤング係数の見かけ上の低下率の值は，P C 部材の断 面, P C 鋼材の緊張応力, $\mathrm{P} \mathrm{C}$ 鋼材の配置形状, 使用子 るシースの直径, センタースパイラルの性質などによ 
って異なるものであることは表一7の多くの現場におけ る実測值にかなりのばらつきがあることからも容易に想 像することができる。

プレストレッシングの際に知っておかなければならな い值は，その現場におけるP C 鋼材の見かけのヤング係 数の值である。この見か人听のグ係数の值に見積り誤 差があれば，正常なプレストレッシングの作業を行なう ことはできなくなる。

緊張計算には試験成績表による P C 鋼材のヤング係数 ではなくて現場で測定したPCケーブルの見かけのヤン グ係数を使用しなければならない。ただ，この場合，そ れぞれのPCケーブルについて異なった見かけのヤング 倸数を採用するてとは非常に不便であるから，各形状の PCケーブルについて測定した平均值を用いるのがよ i.

\section{5. プレストレッシングの管理上必要な PC ケ ーブルの組分け方法}

小丸川橋梁におけるブレストレッシングのばらつきの 娭討の際に，伸びから推定される引張力之荷重計から推 定される引張力の差は 3〜5\% 程度の標準偏差でばらつ くことを述べた。そして，その後他の現場において求め たプレストレッシングのデータについては表一4のよう な結果があらわれており，偶然䛊差によるばらつきの標 準偏差が 3〜5\% 程度となっている。しかしながら，て の考え方の基礎になっている事項はP Cケーブルはその 配置形状のいかんにかえわらず同一母集団からのばらつ きを示し，さらに，PCケーブルの見かけのヤング係数 も各ケーブルについて等しいてとを前提としているので ある。

プレストレッシングの管理において，組分けされた各 組にふくまれるPCケーブルが同等の配置形状を有する 場合，例えば，同一形状の P C 部材を多数製作し 1 本の 部材にふくまれるPCケーブルを一つの組とする場合に ふ，各P Cケーブルが同一母集団とみなされない場合で も各組ごとにまとまれば近似的に同一母集団とみなすて とぶできるので，上記の前提についてはあまり問題にな らない。しかし，組分けの仕方が各組內にふくまれるP Cケーブルが同等でない配置形状を有する場台,例えば， 1 本のP C 部材にふくまれるケーブルが二つ以上の組に 分けられ，それぞれにふくまれるケーブルの配置形状が 異なる場合には各P Cケーブルの母集団の違いが組とし ての母集団の違いとなってあらわれてくることがある。

したがって，PCケーブル 配置形状，す变わち，長 さ，曲げ上げ角度の大きさが異なることによって伸びか らの引張力の推定值と荷重計からの引張力の推定值の間 にどのような差を生じるかを検討して，PCケーブルの 配置形状の差を管理の上においてどのように取り扱うべ
きかを確認しておくことが必要である。

根岸線 $\mathrm{ABC}$ 現場，小丸川橋梁における緊張データを 各ケーブルでとに区別して整理してみると表一9，10の ようになる。根岸線 $\mathrm{ABC}$ 現場は 10 本の $\mathrm{PC}$ 同一ヶ ーブルよりなる同一形状の P C 桁 76 本を製作したので， 配置のPCケーブルがおのおの 76 本ずつ存在する。ま た，小丸川橋梁においては工事の前半におけるマノメ一 ターの指度が正しかったと考えられる 17 本のP C析に ついて，1本の桁に同一配置のP C ケーブルが 2 本ずつ あるので, 同一配置のPCケーブルがおのおの 34 本存 在する。

\begin{tabular}{|c|c|c|c|c|c|}
\hline 表一 & $\begin{array}{l}\text { 根岸線 } \\
\text { 伸ひと }\end{array}$ & $\begin{array}{l}\mathbf{A B C} \text { 現境 } \\
\text { 力計の読 }\end{array}$ & $\begin{array}{l}\text { こおける各 } \\
\text { の差 }\end{array}$ & ケーブル & :との \\
\hline \multirow{2}{*}{$\begin{array}{l}\text { ケーフ } \\
\text { ル番号 }\end{array}$} & \multirow{2}{*}{$\begin{array}{l}\text { ケープル } \\
\text { の長ざ } \\
(\mathrm{m})\end{array}$} & \multirow{2}{*}{$\begin{array}{l}\text { グブルの } \\
\text { 曲げ上げ角 } \\
\text { 度 } \\
(\tan \theta)\end{array}$} & \multicolumn{2}{|c|}{ 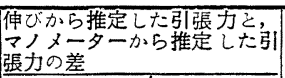 } & \multirow{2}{*}{ 資料数 } \\
\hline & & & 平 均 & 標準偏差 & \\
\hline 1 & 24.3 & 0.35 & +1.32 & 3.45 & 76 \\
\hline 2 & 24.3 & 0.30 & +0.57 & 4.26 & $"$ \\
\hline 3 & 24.2 & 0.25 & +0.65 & 4.06 & " \\
\hline 4 & 24.1 & 0.20 & +1.73 & 3.84 & " \\
\hline 5 & 24.4 & 0.40 & -0.31 & 4.96 & " \\
\hline 6 & 24.5 & 0.45 & +0.26 & 5.05 & $"$ \\
\hline 7 & 23.1 & 0.45 & +1.13 & 4.37 & $"$ \\
\hline 8 & 20.1 & 0.45 & +2.44 & 4.57 & " \\
\hline 9 & 17.1 & 0.45 & +3.60 & 5.62 & " \\
\hline 10 & 14.1 & 0.45 & +7.23 & 4.68 & $"$ \\
\hline
\end{tabular}

表一10 小丸川 No. 1 No. 17 桁における各 PC ヶー ブルごとの伸びと圧力計の読みの差

\begin{tabular}{|c|c|c|c|c|c|}
\hline \multirow{2}{*}{$\begin{array}{l}\text { ケーフ } \\
\text { ル番号 }\end{array}$} & \multirow{2}{*}{$\begin{array}{c}\text { ケーブル } \\
\text { の長ざ } \\
(\mathrm{m})\end{array}$} & \multirow{2}{*}{$\begin{array}{c}\text { ケーブルの } \\
\text { 豊げ上げ角 } \\
\text { 度 } \\
(\tan \theta)\end{array}$} & \multicolumn{2}{|c|}{$\begin{array}{l}\mid \text { 伸ひから推定した引張力と， } \\
\text { マノメーターか推定した引 } \\
\text { 張力の差 }\end{array}$} & \multirow[t]{2}{*}{ 資料数 } \\
\hline & & & 平 均 & 標準偏差 & \\
\hline 1 & 13.0 & 0.448 & +7.41 & 5.55 & 34 \\
\hline 2 & 16.1 & 0.448 & +3.86 & 4.81 & " \\
\hline 3 & 19.0 & 0.448 & +3.79 & 4.91 & $"$ \\
\hline 4 & 22.1 & 0.448 & +1.59 & 3.88 & " \\
\hline 5 & 23.5 & 0.448 & -1.32 & 3.86 & $"$ \\
\hline 6 & 23.5 & 0.448 & -3.38 & 2.73 & " \\
\hline 7 & 23.3 & 0.448 & -0.94 & 3.94 & " \\
\hline 8 & 23.3 & 0.448 & -0.09 & 4.80 & $"$ \\
\hline 9 & 23.2 & 0.392 & +1.15 & 3.30 & " \\
\hline 10 & 23.2 & 0.392 & +0.97 & 3.86 & $"$ \\
\hline 11 & 23.1 & 0.291 & +2.71 & 3.57 & $"$ \\
\hline 12 & 23.1 & 0.291 & +1.03 & 4.84 & " \\
\hline
\end{tabular}

これらの表をみると標準偏差の值は各配置形状のケー ブルのグループごとにまとめてもさして変動は認められ ないが, 平均值はケーブルの配置形状によってかなりの 変動がある。このことは 4. において述べた見かけのヤ ング係数がケーブルの配置形状により異なることによっ ておこるのである。すなわち, 緊張計算では全部のケー ブルに対して同一のヤング係数の值を用いて計算するの で見かけのヤング係数が小さいP Cケーブルにおいては 伸びから推定される引張力が大きくあらわされることに なる。

したがって，ケーブル間に有意差がある場台には管理 の際組に分け，組と組の間の有意差の検定をしようとす 
る目的に対し組内における有意差が大きな影響を与え， 管理の判定を誤らせるおそれがでてくる。現場における 緊張結果からケーブル間の有意差を分散分析によって判 定した結果は 表一11 のようになる。

\section{表一11 ケーブル間の分散分析結果}

\begin{tabular}{|c|c|c|}
\hline 橎 & 分散分析の判定（水準） & 異質ケーフル番号 \\
\hline 小丸川 (No. 1 14 桁) & (0.5\% 以下) & $11^{\prime} 22^{\prime} 33^{\prime} 5^{\prime} \quad 66^{\prime}$ \\
\hline 小丸川 (No. 28 35 & $(" \Rightarrow)$ & $11^{\prime} 22^{\prime} 3$ \\
\hline 井出 川 & $2 \%$ & 8 \\
\hline 根岸線（スパン $20 \mathrm{~m}$ ) & $"$ & 1 \\
\hline 根岸線（スパン $22.5 \mathrm{~m}$ ) & " $\quad\left(\begin{array}{lll}1 \% & 1 \%\end{array}\right)$ & 10 (最短ケーフル) \\
\hline 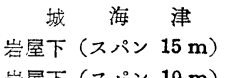 & $\begin{array}{l}\text { 有意とはいえない }(12 \%) \\
\text { 有 } \quad(2.5 \%)\end{array}$ & 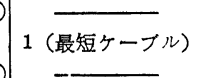 \\
\hline $\begin{array}{l}\text { 岩屋下（スパン } 19 \mathrm{~m} \text { ) } \\
\text { 早 川 (No. 13 20 桁) }\end{array}$ & $\begin{array}{c}\text { 有意とはいえない } \\
\text { " } \quad(80 \%)\end{array}$ & \\
\hline
\end{tabular}

この結果によると, 城海津, 岩屋下 (スパン $19 \mathrm{~m}$ ), 早川のようにケーブル間に有意差が認められない場合も あるが，表一11 の過半数の現場においてはケーブル間 に有意差が認められる。特に小丸川の場合には，有意差 の認められるケーブルが非常に多くなっているが共通し て有意差の認めら机るものは，ケーブル番号 $1,2,3$ の 途中曲げ上げケーブルである。その他, 根岸線 (スパン $22.5 \mathrm{~m}$ ), 岩屋下 (スパン $15 \mathrm{~m}$ ) も途中曲げ上げの短い ケーブルに有意差が認められている。

プレストレッシングの管理において組分けをする場合 には，1本の部材にふくまれるケーブルを一組とするて とがケーブル間の有意差を消去する上から望ましいので あるが，つぎのような場合には部材ごとに一組とするこ とは必ずしも得策ではない。

a) 1 本のP C部材内にふくまれるP Cケーブルの本 数が非常に多い場台 非常に多くのケーブルで一組をつ くると，管理図の点の数が少なくなる。このてとは，何 ふ異常の現象があらわれた場合に異常の発見をおそく し，異常を生じた部材の㚮置が非常に困難になる。この 理由から，一組のケーブル本数は 10 本以下，できれば 5〜7 本程度に選ぶのが望ましい。

b） P C部材のプレストレッシングを何回かにわけて 行なう場合 プレストレッシングを何回かに分けて行な う場合，その間の期間が数日程度であれば別に問題はな いが，一次緊張で何本かの P ᄃ ケーブルを引張ってか ら，二次緊張までに相当の長期間を有するような場合に は，統計的管理という意味から P C部材とは無関係に緊 镸順に何本かのケーブルをまとめて一組とする方法が望 ましいし，異常状態の発見もおくれることがない。

c) 形状寸法の異なった P C 部材を製作する場合 類 似の P C 部材を製作する場合には各部材でとに一組とす ることもできるが，異なる部材につくる場合には，やは り緊張順に何本かずつを一組とするほうが便利な場合も ある。

以上のように実際には, 一つの部材の中のケーブルを
いくつかの組に分けたくなることがおこってくる。 小丸川, 根岸線, 井出川について 1 本の析にふくまれ るPCケーブルをいろいろの組に分け, 分散分析によっ て組間の有意差の判定を行なってみた。

小丸川については No. 1〜No. 14 の桁は桁間におい て有意差はないものと認められるので, てれらの桁につ いて組分けの影響を調べて見た。組分けの方法は, 一組 内のケーブル本数が 4 本, 6 本, 12 本の場合を選んで それぞれの場合について緊張順に組分けをして行く方法 と, 種々の配置形状のケーブルが各組にほぼ均等に分け られるように適当に組分けする方法について比較してみ た。この結果は 表一12 に示すように緊張順に組分けし た場合には, 各組に有意差のあるケーブルが均等に分配 しないため，どの大きさの組に対しても組間に有意差が あり，しかも高度に有意であるという判定となってい る。乙机に対して組分けを適当に行なった場合には，い ずれも組間の有意差は認められない。

\section{表一12 小丸川橋 (No. 1～14 桁) の分散分析結果}

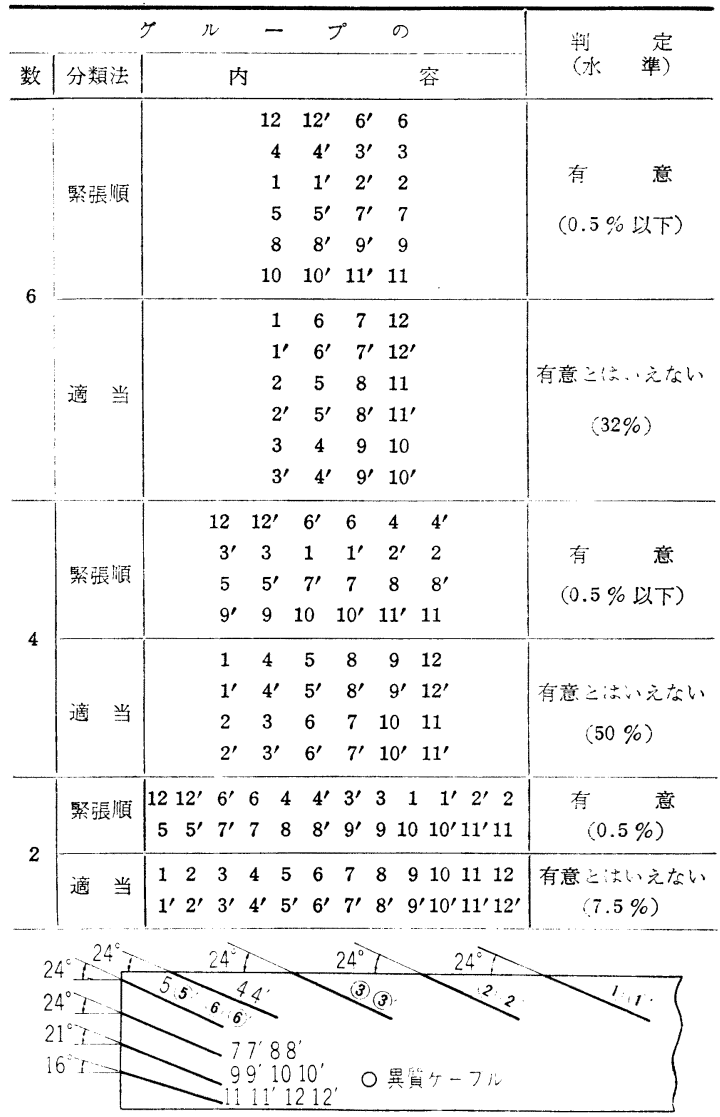

井出川については1本の桁にふくまれる12 本のケー ブルを 4 本， 6 本の組に分けてみた。その結果は表一13 に示すとおりであるが, 緊張順に組分けを行ふっても適 当なる組分けを行なった場合も，いずれも組間に有意な 差は諗められない。表一10 に示すように井出川の場合 
合には，有意な差を有するケーブルは No. 8 だけであ り，有意の程度もあまり高くないのでての有意な差がグ ループ分けに影響を与えないという結果になった。

表一13 井出川橋の分散分析結果

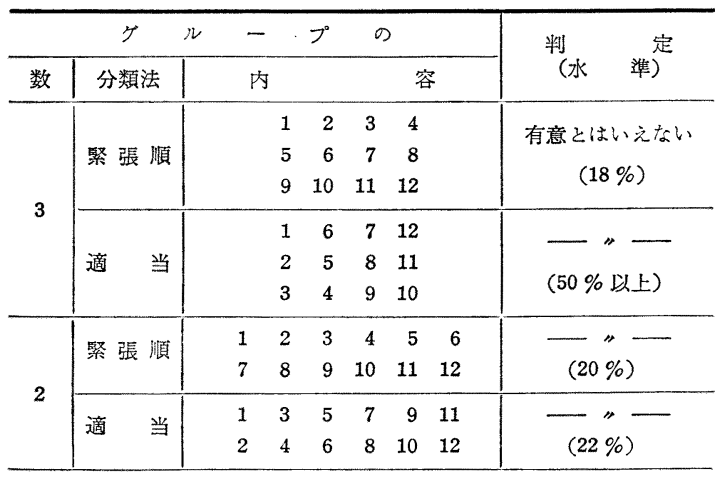

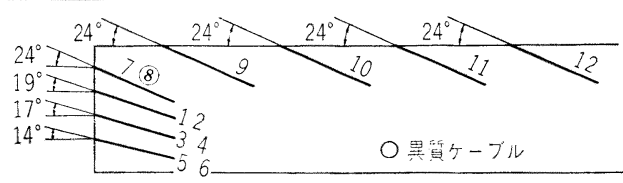

てれに対して, 根岸線の場合には小丸川の場合と全く 逆の判定結果があらわれている。すなわち，表一14 亿 示すとおりである。

\section{表一14 根岸線（スパン $20 \mathrm{~m}$ ) の分散分析結果}

\begin{tabular}{|c|c|c|c|c|c|}
\hline \multicolumn{5}{|c|}{ タループの } & \multirow{2}{*}{ 判定 (水準) } \\
\hline 数 & 分 類 法 & 内 & & 容 & \\
\hline \multirow{4}{*}{3} & 時間的な緊張順 & $\begin{array}{l}\text { (1) } \\
\text { (4) } \\
\text { (7) }\end{array}$ & $\begin{array}{l}(2) \\
(5) \\
(8)\end{array}$ & $\begin{array}{l}\text { (3) } \\
(6) \\
(9)\end{array}$ & $\begin{array}{c}\text { 有意とはいえない } \\
\text { (50\%以上) }\end{array}$ \\
\hline & 枌単位緊張順 & $\begin{array}{l}1 \\
4 \\
7\end{array}$ & $\begin{array}{l}2 \\
5 \\
8\end{array}$ & $\begin{array}{l}3 \\
6 \\
9\end{array}$ & - \\
\hline & 枌単位配列順 & $\begin{array}{l}1 \\
2 \\
7\end{array}$ & $\begin{array}{l}5 \\
3 \\
8\end{array}$ & $\begin{array}{l}6 \\
4 \\
9\end{array}$ & - \\
\hline & 桁単位適当 & $\begin{array}{l}1 \\
3 \\
4\end{array}$ & $\begin{array}{l}2 \\
5 \\
6\end{array}$ & $\begin{array}{l}9 \\
8 \\
7\end{array}$ & 有 \\
\hline
\end{tabular}

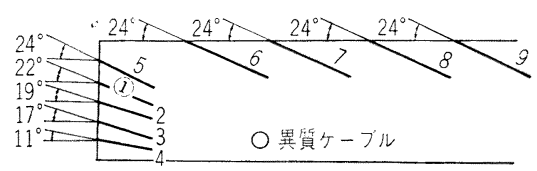

根岸線の場合には，プレストレッシングを 2 回に分け て行なった。第1 回のプレストレッシングの際に 6 本の PCrーブルを緊張し 2 3 週間後に残りのケーブルを 緊張する方法をとった。てのため組分けの方法として一 組を 3 本とし，時間的に緊張した順序に組分けをする方 法, 各栴ごとで緊張順に組分けをする方法, 1 本の P C 桁に配置されているケーブルを一方の端から配列順に 3 本ずつに分ける方法, そして最後に 1 本の P C 桁内にお いて配置形状がほぼ均等になるような組分けの方法を選 んだのであるが, 分散分析の結果は各組間に有意差をな
くしようとして適当に選んだ組分けの場合だけが組間に 有意差を認めるてとになり，予想とは逆の結果になっ た。しかし，乙の場合，有意の程度は小さい。

井出川，根岸線の場合には有意差のあるケーブルが配 置形状の差之は無関係化あらわれている。特に，根岸線 の場合のように適当に組分けをしたものが, 有意差を生 ずるような結果になったが，配置形状に無関係化有意差 のあるケーブルがあらわれる場合には，特別な理由がな いかぎり有意差の程度は一般に小さいものと考えること ができる。小丸川の場合の有意差は $0.5 \%$ の危除度で い光るのに対し, 根岸線の場合には $2.5 \%$ の危険度に なっている。したがって, 根岸線の場合のように適当に 組分けした場合にかえって有意になっても，それが管理 の実施上に影響するところは小さいものと考えることが できる。

各種の組分けの方法によって管理図を描いてみると図 -14，15のようになる。図一14 は小丸川橋梁において 統計的な管理状態にあった No.1〜No.14 までの 14 本 のP C栴の 336 本のP C ケーブルについて, 伸びから推 定される引張力之荷重計から推定される引張力の差を引 張力の％であらわした值を個々のケーブルについて， また，各種の組分けを行なった場合の平均値を管理図の 形にプロットしたものであるが，個々のケーブルについ ての分布を求めると平均值が $+0.98 \%$ (平均的に伸ご から推定される引張力が $0.98 \%$ 高くなる), 標集偏差 $4.37 \%$ となる。乙れを母集団の平均值，標準偏差であ ると仮定し，正規分布であるとすると $2 \sigma$ をはずれるケ ーブルは約 $5 \%$ 存在する。そして同様に $n$ 本を一組とし た場合には，2 $\sigma / \sqrt{n}$ をはずれる資料が約 $5 \%$ できな くてはならない。しかし実際には緊張順に $n$ 本で之を一 つの組とした場合には，2 $/ \sqrt{n}$ をはずれる資料がずっ と多くなる。このととはグループ分けの方法が不適当の 場合には管理図の判断を䛊らせ，正常な管理状態にある 場合にも，異常な状態が生じたという判断をさせる場合 が非常に多くなってくる。この結果，管理図の実用性を なくすととになるので, 組分けの問題は非常に重要であ る。そしてケーブルの配置形状の類似のものが各組に注 ぼ等分されるように組分け方法をとることの必要性を示 している。

一方, 井出川橋梁については 図一15 示すとおりであ る。

井出川橋梁においては，先の表一13 亿おいてどのよ うな組分け方法を行なっても有意差は認められなかった が, 図一15 においても類似の 結果を与えている。广な わち，PC ケーブル6本を一組とする場合には，2。の 範囲をはずれる P C ケーブルの割合は緊張順にとったる ののほうが適当な組分けを行なったものより理論值に近 い結果を与えており，PCケーブル 4 本を一組とする場 
図一14 小丸川橋梁 P C 緊張管理図（各林の組分けについての比較）

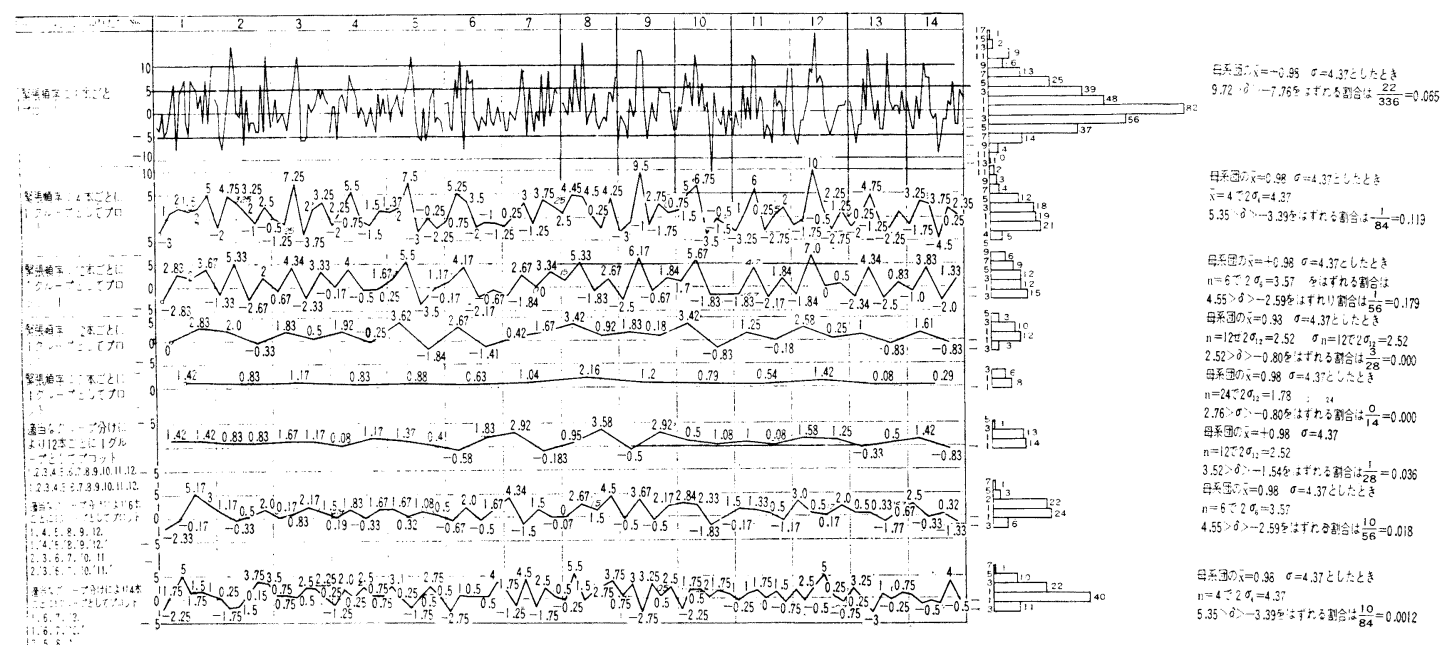

図-15 井出川橋梁 P C 桁䋈張管理図（各桁の組分けについての比較）

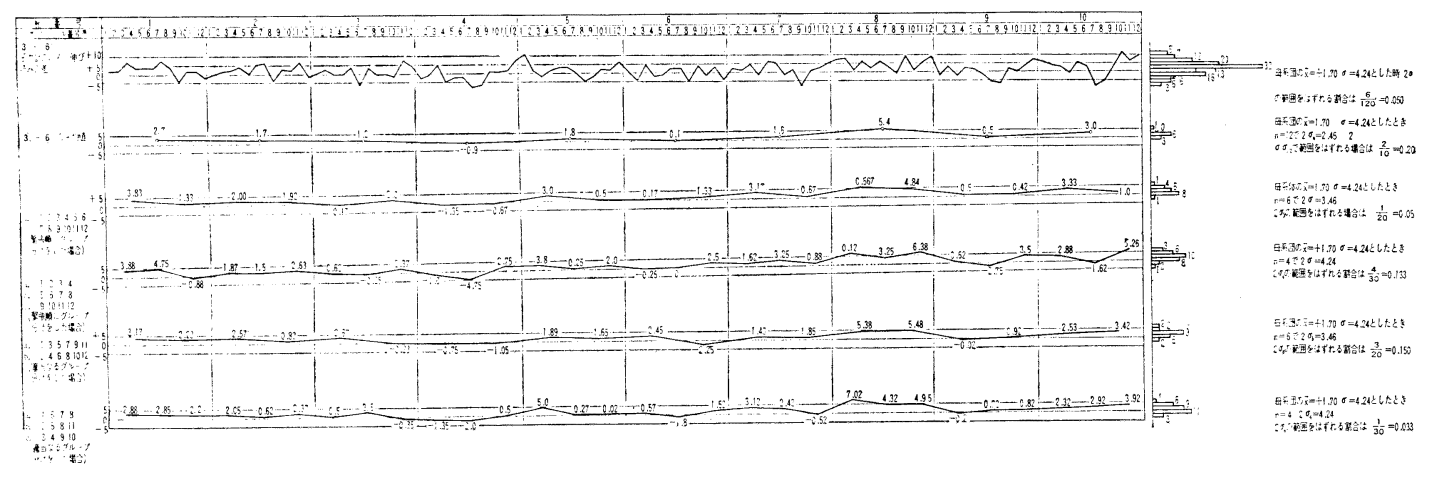

には，その逆の結果を与えている。そして組分けの方法 の差による影響はあまり明瞭でないということができ 万。

図一-15において非常に興味ある点は, No. 8 の P C 妳においては個々のケ -ブルについては $2 \sigma$ の範囲をは ずれる P Cケーブルがないのにもかかわらず, 組に分け た平均值で管理していく場合には，その組分けの方法が どのように行なわれた場合にも共通して，2 $\sigma$ の範囲を はずれる組があらわれているてとであり，組による管理 方法の利点を明らかにあらわしている。

組分けの方法がプレストレッシングの管理にどのよう な影響を与えるかを三つの現場について検討してみた。 その結果は上記のように三者三様であり, 組わけについ て十分慎重に考慮しなければならない場合もあり, また 逆に, 組分けについて十分な考慮を行なっても何の役に もたたない場合もある。そして，これは現場の条件によ ってまちまちであるということができる。

ここで結論としていうことができるのは，P Cケーブ ルの配置形状を考慮して適当なる組分け方法を行なった 場合の害がプレストレッシングの管理のうえにおよぼす
影響は小さいが, 適当なる組分け方法を行なわなかった 場合の害がプレストレッシングの管理のうえにおよぼす 影響は非常に大きいということである。したがって, 統 計的管理の効果を十分に生かそうとするには各組が同一 母集団と考えられるように，常に適当な組分け方法を選 ばなければならない。

\section{6. 各種の 摩擦がプレストレッシングの 誤差に およぼす影響}

これまでの考察においてもうかがわれたように，P C ケーブルが弯曲しているということが P C 鋼材の見かけ のヤング係数を考えなければならないような結果を生じ させ，また，シースとPCケーブルとの間の摩擦による 引張力の損失が高い精度を要求されるプレストレッシン グを複雑にするもっとも大きな要素となっている。

このようにプレストレッシングにとって，もっとも重 要な要素の一つである摩擦係数については, いわゆる摩 擦試験によってその值を知る手段がある。ただ，ての摩 擦測定試験によってわれわれが知ることができる摩擦係 数について, われわれはどの程度の信頼度をおくととが 
できるか子理解し，また，ての摩擦係数についての表現 をぞのように簡略化してプレストレッシングの管理の手 段に導入するかを検討してみる必要があるであろう。

\section{（1） ジャッキおよび定着具の内部摩擦係数}

PCヶーブルの端部において，P C 鋼材が定着具内に おいて曲げられるため定着具と P C 鋼材の間にシース内 亿わけるとは別の摩擦を生じ，でく短い区間においてP C鋼材に与兄られる引張力が低下する。

ジャッキおよび定着具内における摩擦損失が，計算に おいて仮定したものと異なると荷重計のキャリブレーシ ヨンをいかに入念に行なっても意味がないことになって しまう。

フレシネー方式の実橋において行なった従来の測定例 を示すと 表一15 のよ うな值になっている。 表一15 ジャッキおよび定着具 また，実験室内におい て定着具および $\mathrm{P} \mathrm{C}$ 鋼 材の表面の状態をいち じるしく変えて, この 内部摩擦係数を測定し た結果は 表一16 亿示 すとおりである。これ らの結果淿るる，定 着具および P C 鋼材の さびの状態によって摩 擦係数は影響されるこ の内部摩㨲損失測定值

とがわかるが，一般の現場においてはさびの全然ないも のを使用することは少ないので，実橋における測定の結 果のばらつきは比較的小さい值を示しており標準偏差で $1 \%$ 程度である。

\section{表一16 P C 鋼材および定蓄具のさびの状態による内部摩撚} 損失係数の差

\begin{tabular}{|c|c|c|}
\hline 定着具の状態 & $\begin{array}{l}\mathbf{P C} \text { 鋼材の表 } \\
\text { 面の状態 }\end{array}$ & $\underset{r}{\text { 摩擦損失係数 }}$ \\
\hline $\begin{array}{l}\text { きひなん } \\
\text { きむか }\end{array}$ & $\begin{array}{l}\text { さびなし } \\
\text { さびあり }\end{array}$ & $\begin{array}{l}0.020 \\
0.053\end{array}$ \\
\hline
\end{tabular}

\section{（2） P C 鋼材とシースとの接触摩擦係数}

$\mathrm{PC}$ 鋼材とシースとの接触摩擦係数は, 一般に $\mathrm{PC}$ ケ ーブルの単位曲げ角度あたりの摩擦損失係数 $\mu$ 之 P C

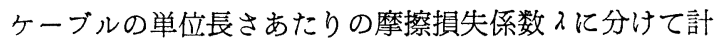
算されており，これが実際のケーブル内の応力分布と一 般的によく一致するものであるてとは，参考文献 ${ }^{4), 19}$ に よる実験結果に示されている。

実橋の施工の際に測定された P C 鋼材とシースとの接 触摩擦係数は表一17 に示すとおりである。表一17 に示 す值は各現場において何本かのケーブルについて摩擦測 定武験を行ない，その結果から最小自乗法によって よび ג (ての場合便宜上 $\lambda / \mu$ の值で示す) を計算した值 である。
てれらの現場にお いて求めた

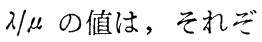
れ異なった本数のP Cケーブルの摩擦試 験から求めた值であ るので，それぞれの 值の重みは同一では ないが便宜上同一の 重みとして平均値お よび標準偏差を計算 した結果， $\mu$ の平均 值 0.385 , 標準偏差 の推定值 $0.08, \lambda / \mu$ の平均值 0.0157 , 標準偏差の推定值 表一17P C 鋼材とシースの間の接 触摩擦係数の実測值

\begin{tabular}{|c|c|c|}
\hline 橋 梁 名 & $\mu$ & $\lambda / \mu$ \\
\hline 須 & 0.5 & 0.0048 \\
\hline$"$ & 0.3 & 0.0247 \\
\hline 信 & 0.33 & 0.0333 \\
\hline 藤 & 0.46 & 0.0117 \\
\hline 釈 迦 堂 川 & 0.38 & 0.0068 \\
\hline 安 治 川 & 0.54 & 0.0143 \\
\hline 八 雲 第 一 & 0.46 & 0.0096 \\
\hline 八 雲 第 二 & 0.40 & 0.0050 \\
\hline 上松 川 & 0.26 & 0.0216 \\
\hline 金 鋼 大 橋 & 0.28 & 0.0196 \\
\hline 米代 川 & 0.43 & 0.0088 \\
\hline 小丸川（前半） & 0.35 & 0.0209 \\
\hline "（後半） & 0.42 & 0.0144 \\
\hline 第 一 桜 川 & 0.36 & 0.0194 \\
\hline 弁 天 町 & 0.31 & 0.0207 \\
\hline 平 & 0.385 & 0.0157 \\
\hline 漂 汻 偏 差 & 0.08 & 0.0081 \\
\hline
\end{tabular}
0.0081 となる。

プレストレッシングの作業のための緊張計算を行なう 場合，また，プレストレッシングの管理の手順を簡単に しようとする場合, 摩擦損失についての三つの変数をで きるだけ簡単な形にして処理するようなととを考える必 要がある。

てのためには，三つの摩擦損失係数のうちどの係数が 緊張力の誤差にもっとも大きな影響を与え，しかも大き なばらつきの原因になるかを知り，そのうえで簡略化の 方法を決め，簡略化された方法によっても実用上の害の 女いととを確かめなければならない。

三つの係数が緊張力の低下におよぼす影響の程度はケ ーブルの配置形状, 長さによって異なるはずである。わ れわれが通常製作する部材は曲げ上げ角度が $0.1 \sim 0.5$ ラジアン,ケーブル長さは $10 \sim 40 \mathrm{~m}$ を考えておけば橋 析用の P C 部材としては十分な範囲であり, 他の部材に おいても大体ての範囲におさえられている。てれらの範 囲で, 表一15 および表一17 亿求めた摩擦損失係数が, 緊張力の低下におよぼす影響の大きさを計算してみると

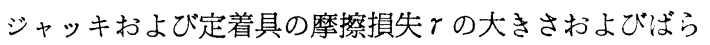
つきは，PCヶーブルとシースの接触摩擦損失（ $\mu$ およ びスの影響によるもの）のそれらにくらべて一般に小さ く,また, 絶対值としてもプレストレッシングのばらつ きに大きな影響を与えるほどのものではない。したがっ てフレシネー方式の定着具の場合には，ジャッキおよで 定着具の摩擦損失試験を行なうことを推奖するが一般的 には $5 \%$ の損失を考光て緊張計算を行なえばよいであ ろう。その他の工法についても, ほぼ同程度あるいはそ れ以下と考えられるので, 特定の定着方式についてのシ ヤッキおよび定着具の摩擦損失の大きさをあらかじめ試 験によって求めておけば一般的にてれを使用して緊張計 算を行ない，てれによるばらつきを多くのばらつきの要 
素の一つと考えるととによって処理しても十分目的を達 するととができる。

PCヶーブルとシースの間の接触摩擦損失は一般的に

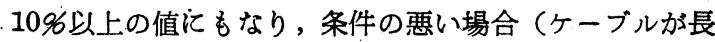
く，曲げ上げ角度が大きい場合）には $20 \%$ 以上にもな るととが考えられるので，摩擦損失の值については慎重 亿取り扱う必要がある。P C鋼材の伸びによって引張力 を推定する場合に見かけのヤング係数が直接的な影製を 与えるように荷重計の読みによって引張力を推定する場 合には，PCヶーブルとシースの間の摩擦損失が直接的 な影幚を与える。しかも，見かけのヤング係数か $5 \%$ 程 度の標準偏差で影響を与えるのにくらべて摩擦損失は, 現場の条件が変わってくると $10 \%$ 程度にも達する標準 偏差で影䍺を与える。

てのようにプレストレッシングによって重要な要素で あるが, 摩擦測定試験からわれわれが直接求められる值 は $\mu \alpha+l \lambda$ であって， いては知ることができない。このため，何本かの $\mathrm{PC}$

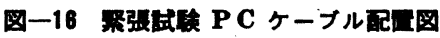
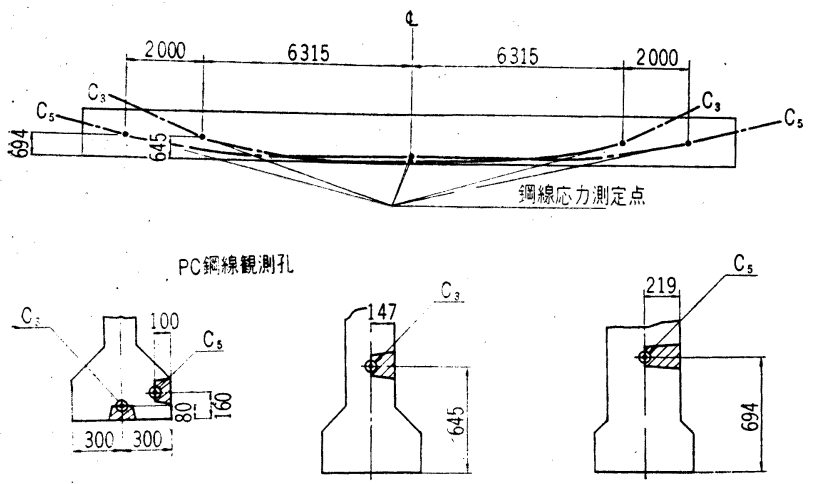

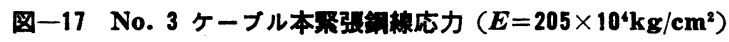

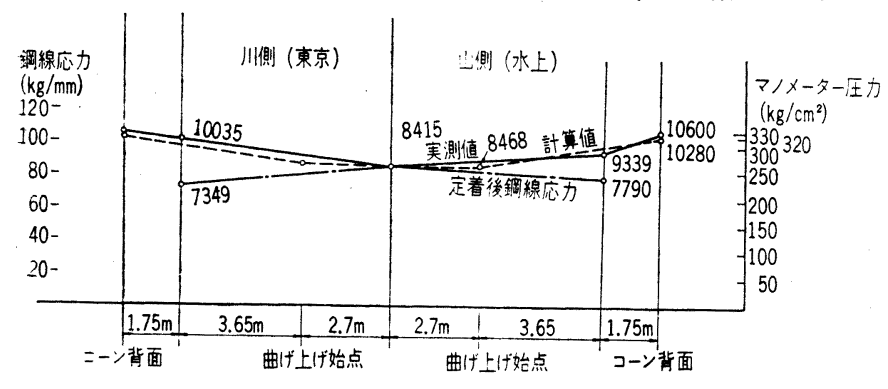

\author{
計算応力 $320 \mathrm{~kg} / \mathrm{cm}^{2}$ \\ 計算伸び $77 \mathrm{~mm}\left(E_{p}=205 \times 10^{4} \mathrm{~kg} / \mathrm{cm}^{2}\right)$ \\ 実剆応力 $330 \mathrm{~kg} / \mathrm{cm}^{2}$ \\ 実測伸び $79 \mathrm{~mm}$ \\ スパン中央所要緊張力 $81.9 \mathrm{~kg} / \mathrm{mm}^{2}$ \\ 緊張時スパン中央計算応力 84.0 \\ めり込み $5.5+3.5 \mathrm{~mm}$
} 力の差については, 図一17, 18 ならびに 丧一18 に示すように 2 5 96 程度であり，われわれが通 常予期しなければならない程度の誤差である。

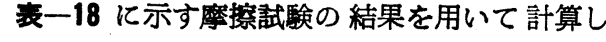
た応力比は試験を行なった杵の前に製作した桁に 最小自乗法によって, 摩擦係数 $\mu$, を求め応力 減少を計算したものである。

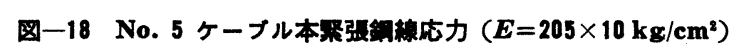

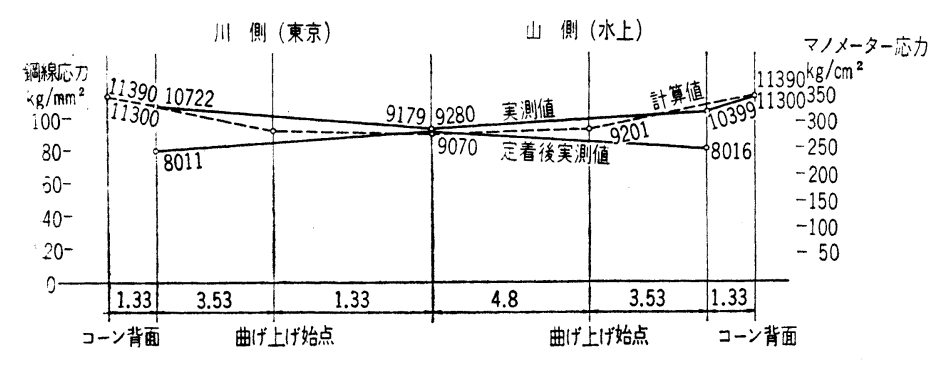
計算応力 $353 \mathrm{~kg} / \mathrm{cm}^{2}$
計策伸ひ $96.5 \mathrm{~mm}$
実测忘力 $350 \mathrm{~kg} / \mathrm{cm}^{2}$
スパン中央所要緊張力 $89.4 \mathrm{~kg} / \mathrm{mm}^{2}$
婪張時中央計算姀張力 $90.7 \mathrm{~kg} / \mathrm{mm}^{2}$
めり込み $4.5+4.5 \mathrm{~mm}$ 
表一18 摩擦による応力減少

\begin{tabular}{|c|c|c|c|c|c|}
\hline & $\begin{array}{l}\text { 緊張端鋼線応 } \\
\left.\mathbf{n g} / \mathbf{m m}^{2}\right)\end{array}$ & $\begin{array}{l}\begin{array}{l}\text { スパン中央鋼 } \\
\text { 線応力 } \\
\left(\mathrm{kg} / \mathrm{mm}^{2}\right)\end{array} \\
\end{array}$ & $\underset{\text { (a) }}{\text { 応力比 }}$ & 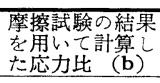 & $\mathbf{b} / \mathbf{a}$ \\
\hline No. 5 ケーブル予備緊張 & 113.00 & 93.8 & 1.21 & 1.28 & 1.06 \\
\hline No. 5 ケーブル本緊張 & 113.00 & 92.6 & 1.22 & 1.28 & 1.05 \\
\hline No. 3 ケーブル予備緊張 & 106.00 & 85.2 & 1.25 & 1.22 & 0.98 \\
\hline No. 3 ケーブル本緊張 & 106.00 & 83.1 & 1.28 & 1.22 & 0.96 \\
\hline
\end{tabular}

(b) こは $\mu=0.45 \quad \lambda=0.003$ 在得心

本実験において，応力測定を行なった場所はスパン中 央のほか曲げ上げ途中 2 点であったが，曲げ上げ途中の 点での応力はその点での計算による応力と必ずしも一致 していない。川および入が伸びおよび荷重計の読みにど のような影響を与えるかについては，学会論文集 76 号 所載の小丸川橋梁における研究で論じてあるが, 同一形 状ケーブルにおいて荷重計の読みに対しては $(\mu \alpha+l \lambda)$ という值で関係してくるので，仮りに $\lambda / \mu=$ 一定とし て，変数を $\mu$ だけの関数と考えてもさしつかえない。一 方, 伸びの值は $\mu \alpha+l \lambda$ が一定の場合でも $\mu$ と $\lambda$ の組 台わせが異なるてとによって影響される。ただ，われわ れが 推定した值であり，個々の PC ケーブルにおける るいはスではないのである。そして上に述べた実験結 果にもあらわれているように個々のP Cケーブルにおい ては, 計算から出された $\mu$ と の個々の值は必ずしも 実際の $\mu, \lambda$ の值をあらわしていない。このように よび $\lambda$ が仮想の值であり, 個々の PCケーブルではこ の仮想の値と異なった值を示すのであるから，むしろ $2 / \mu$ を一定と考えてしまうほうが管理を簡単化するうえ

\section{図一19 $\mu$ と $\lambda$ ，組合わせの変化がケーブルの伸びと端} 部引張力の関係に与える影響
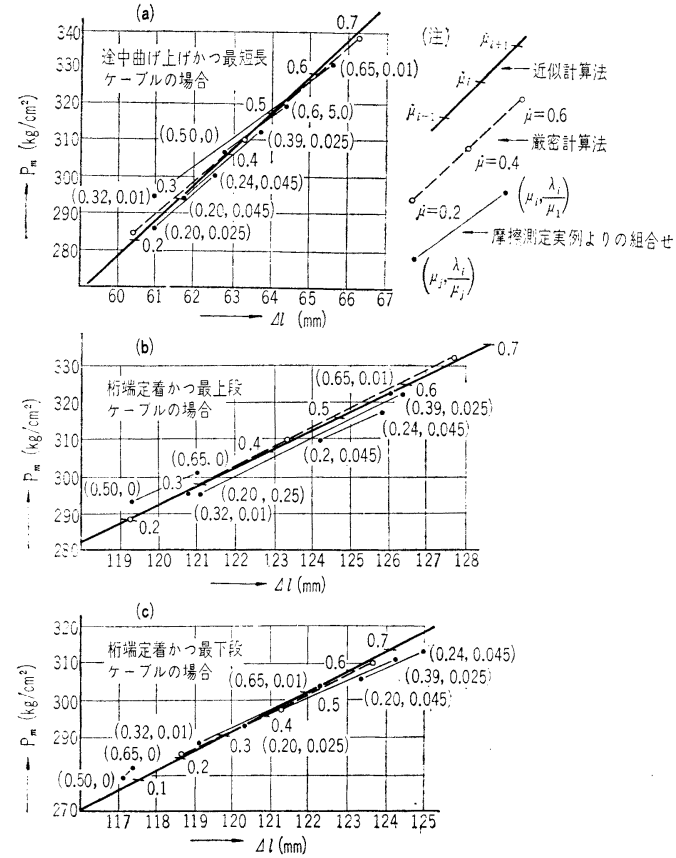

から有利ではないかと考えられる。

$\lambda / \mu$ を一定と考えて緊張計算を行なっ てもよいかどうかは，このためにあらわ れる䛊差の大小によって決まるものであ る。スパン $25 \mathrm{~m}$ の代表的な鉄道橋用 のP C析について， $\lambda / \mu=$ 一定とするこ との影響を試みた。なお，このとき緊張 計算に応力分布を一次式で考えた普通近似式と応力分布 の変化を指数関数之考えた敩密式を用いた場台との比較 も一緒に試みた。その結果は図一19 に示してあるが， この図から判断するのに，表一17 に示す $\lambda / \mu$ の変動の 範团であれば実用上は $\lambda / \mu=$ 一定（この場合，学会 P C 指針の $\mu=0.3, \lambda=0.004$ より $\lambda / \mu=0.0133$ とした） と考えても，P C鋼材の伸びと端部引張力との関係に大 きな影響は与えず，十分実用上の目的を達するものと考 えられる。また，緊張計算として近似式を用いても十分 実用的であることも了解するてとができる。

本章においては, 各種の摩擦係数がプレストレッシン グの䛊差におよぼす影響について検討してみた。この結 果，シースと P Cケーブルとの間の摩擦係数がプレスト レッシングにおよぼす影響は非常に大きいのであるが， 複雑な摩擦損失の表現方法を $\mu$ だけの関数であらわし ても，実用上十分であることを確認することができたの である。

\section{7. プレストレッシングの管理 における 統計量 の選択に関する検討}

\section{(1) 統計量に関する理論的考察}

小丸川橋梁工事におけるプレストレッシングの䛊差の 研究に際して，プレストレッシングの管理を行なう場合 に，伸びから推定される引張力と荷重計から推定される 引張力の差を統計量として選定するのがよいことを提案 した。そして，ての考え方はてれまでの現場において実 用され，実用上大きな欠点のないことが示されている。 しかし，6.までに述べたように，各種の問題点が明ら かにされたので，再び管理方法，特に統計量についての 理論的，実用的な柍討を行ない，より合理的で，しかも 実用上，簡単に使用できる統計量について検討を行なっ てみることにする。

これまでの研究によってプレストレッシングの際, 荷 重計による测定方法には摩擦係数が㨁接に関係し，摩擦 係数のばらつき，あるいは見積り誤差が荷重計から弓張 力を決める場合に，もっとも支配的な影響を与えること が明らかになっている。一方，伸び测定から引张力を決 める場合にも，各種のばらつきの要素が介入してくる が，乙れらを総合して，P C 鋼材の見かけのヤング係数 という概念にまとめることができ，乙の見かけのヤング 係数が P C 鋼材のヤング係数より低い值となるととが明 
らかになっている。

そこで, プレストレッシングに介入して!るばらつ き，または誤差を摩擦係数と見かけのヤング係数という 二つの要素にしばって考えてみると統計的な管理に対す る概念をかなり簡単化するてとができる。

ある 1 本のPCヶーブルを緊張する場合，われれれは P C 鋼材端部の緊張力を荷重計によって知り，P C ケー ブルの平均的な引張力を $\mathrm{P} \mathrm{C}$ 鋼材の伸びから知ることが できる。そして，この二つの測度から設計断面において 所定の引張力を与える点はどこにあるかを知ろうとす る。すなわち,図一20に おいて横軸に伸び, 縌軸 に端部緊張力をとった場 合，所定の引張力を与え る計算上の点がA点であ るとする。しかし，種々 のばらつき，あるいは䛊 差が介人してくるため, 実際の緊张にあたって計 算上の引張力を得る点が

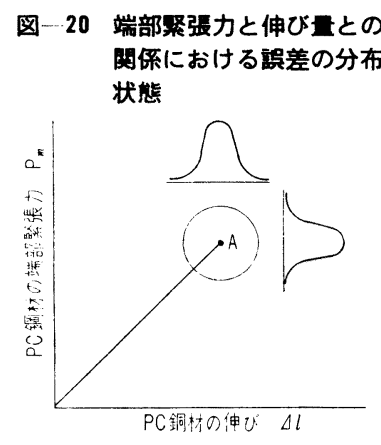

A 点に一致することはなく，A点付近に平面的にばらつ いた点となる。さて，乙の平面的なばらつきを表現する のに，先に述べた摩擦係数と見かけのヤング係数という 二つの值を求めると非常に便利である。なぜならば, 今, 設計断面における所定の緊張力, ジャッキのピスト ンの断面積, P C ケーブルの曲げ角度, PCヶーブルの 長さの要素を定数とすれば, 緊張計算より所定のジャッ キ圧 $P_{m}$, 所定の伸び量 $\Delta l$ はつぎの関数型であらわさ れる。

$$
\begin{aligned}
& P_{m}=f(\mu, \lambda, r) \\
& \Delta l=g\left(\mu, \lambda, r, \stackrel{\circ}{E}_{p}\right)
\end{aligned}
$$

$こ こ に, \mu, \lambda$ : シースと P C 鋼材との摩摖係数でケ一 ブル単位曲げ上げ角度による係数 $\mu$ ，ケーブ ルの波打ちによる単位長さによる係数 $\lambda$ $r$ : ジャッキおよび定着具の内部摩擦係数 $\stackrel{\circ}{E}_{p}: \mathrm{PC}$ 鋼材の見かけのヤング係数 つぎに，上の式における変数 $\mu, \lambda, r, E_{p}$ などのうち

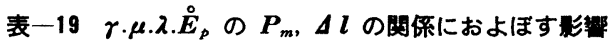

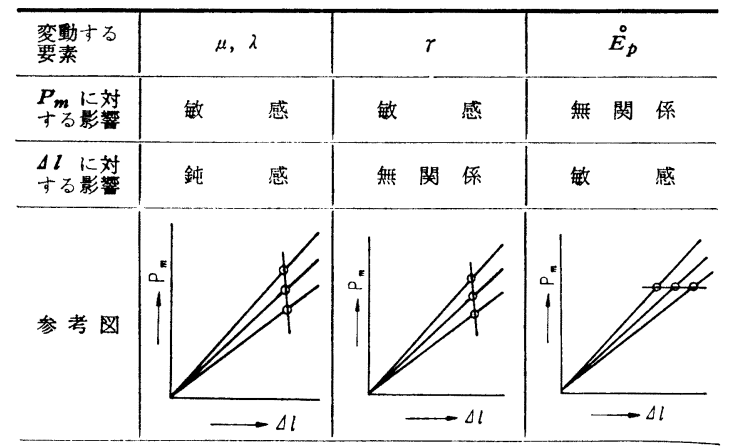

一つが変動する場合, それが $P_{m}$ と $\Delta l$ の関係を示す 威上に方いて，どのようにあらわれるかを計算してみる と表一19 のようになる。

このように摩擦に関係する要素は伸び $\Delta l$ の值に影響 する仕方が非常に鈍く， $\stackrel{\circ}{E}_{p}$ は端部緊張力 $P_{m}$ に全然関 係を抢よぼさない。したがって，図一20における所定 の緊张力を示す点を図一21 のように摩擦係数 場合，4. において論じたように摩擦係数を $\mu$ だけの関

図一21 $\mu, \stackrel{\circ}{E}_{p}$ による $P_{m}, \Delta l$ の関係のばらつきの表現

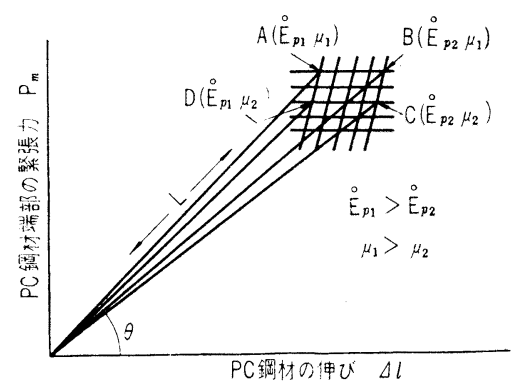

数であらわす) と見かけのヤング係数 $E_{p}$ による網目上 の一点としてあらわすてとができる。すなわち, 設計断 面においてある一定の緊張力を与えようとする場合, 摩 擦損失係数 $\mu$ 之見かけのヤング係数 $\dot{E}_{p}$ が変化する之, その組合わせによって A,B,C,D,ㄷとうう点であらわす ことができる。

ことで，プレストレッシングの管理の本質にもう一度 立ち州ってみることにしよう。設計断面に与えられる緊 張力を管理して行くためには, つぎの二つの条件が満足 されなければならないのである。すなわち，

(1) 外的条件, 例えば, 摩擦係数, 見かけのヤング 係数, 荷重計のキャリブレーションなどが統計的に管理 された状態にあるてと。

(2) 外的条件が管理されたうえで所定の緊張力が与 えられる引き止め点を決めること。

小丸川橋の工事の際の研究の結果として, 提案された 管理方法は（1）の外的条件を管理して行く方法であり， (2)については, 特に, 統計的に管理して行くというと てろまで行っていない。

統計的管理の理想的な形態としては，(1) と（2）の問 題を同時に管理して行く方法である。図一21の $\mu$ 之 $\stackrel{\circ}{E}_{p}$ の二つの変数について統計的な管理を行なって行くてと ができるとすれば，乙れは（1）と（2）を同時に管理して 行くことができるのであるが，てのような 2 変数の統計 的な管理を簡単な方法で実用化することは不可能であ り,やはり統計的管理の統計量は1変数とすべきである。 このためには 図一21 に示す網目による 2 変数の条件を 1 変数㶕略化するてとを考えなければならない。すな わち，一つの変数を常数におきかえなければならない。

図一21における $E_{p}$ を常数とおくと，つぎのような 
図一22によってあらわすととができる。

図一22 $\stackrel{\circ}{\boldsymbol{E}}_{p}$ を一定とした場合の $\boldsymbol{P}_{m}, \Delta l$ の関保の ばらつきの表現

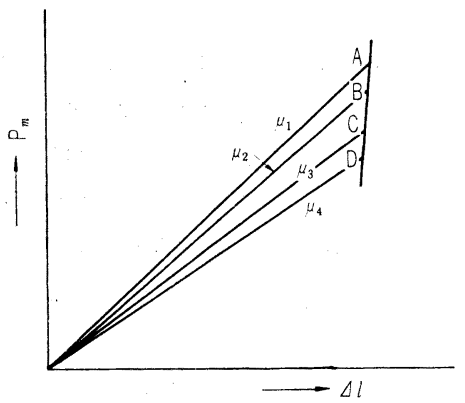

すなわち， $\stackrel{\circ}{p}_{p}$ を適当な值に仮定すれば，摩摖係数が $\mu_{1}, \mu_{2}, \mu_{3} \cdots$ 之変化するにしたがってP C ケーブルの引き

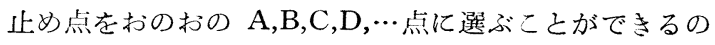
である。ての考えを実用する場合には，ある仮定した $E_{p}$ について, 摩擦係数が $\mu_{1}, \mu_{2}, \mu_{3}, \mu_{4}, \cdots$ の各場合につ いて緊張計算を行なっておき，実際にPCケーブルを緊 張する場合に $P_{m}$ と $\Delta l$ の関係をプロットして行き，と の伸び一圧力直線が $\mathrm{A}, \mathrm{B}, \mathrm{C}, \mathrm{D}, \cdots$ 線と交わった点を引き 止め点之すればよいわけである。ただての場合， $E_{p}$ の 選び方に問題が残る。というのは選ばれた PCケーブルの見かけのヤング係数が一致している場合 には，てのような引き止め点の選び方でよく，また，伸 び一圧力直線の軌跡の $\mu$ がそのケーブルの実際の摩摖 係数を示すことになるのであるが, 選ばれた $\stackrel{\circ}{E}_{p}$ と実 際のPCケーブルの見かけのヤング係数が一致していな い場合には，てのように選ばれた引き止め点では正確な 引張力が与えられないし，また，伸び一圧力直線の軌跡 の $\mu$ が，そのケーブルの摩擦係数をあらわさなくなる。 てれはあくまで手順を簡略したために生ずる誤差であ る。したがって，てのような方法によっても十分満足な 引き止め点を求めるてとはできない。しかし，P C 部材 として引張力が所定の值より多少多目に与えられている ほうが安全である。そして, 引き止め点を決める場合, 引張力が不足する可能性を少なくしようという目的であ れば，その解決方法は比較的簡単である。

図一23において, 見かけのヤング係数の平均値 $\stackrel{\circ}{E}_{p}$, 標準偏差 $\sigma_{E_{p}}$ が 既知であるとすると引き止め点を決め る $\dot{E}_{p}$ を決める場合, $\stackrel{\circ}{E}_{p}$ $=\stackrel{\circ}{\bar{E}}_{p}-n \sigma_{E_{p}}$ とし $n$ を適 当に選ぶととにって， その引き止め点で止めた 場合, 引張力が設計で考 えた値より小さくなる確 率をある值以下にするこ とができる。

小丸川橋梁における研
究において提案した方法によると $\stackrel{\circ}{E}_{p}, \bar{\mu}$ という計算上 の一つの点を基準として考えているわけであるが，ての ようにするととによって，弚 止め点を決めるてとができる。4、において論じたよう に问じ現場における $\sigma_{E_{p}} / \stackrel{\circ}{E_{p}}$ は $5 \%$ 程度の值であるの でこの程度の超過引張力であれば P C 鋼材の許容引張力 に対して，あまり問題になることはない。

てのように引き止め点を決めるための $\stackrel{\circ}{E}_{p}$ が決ま机 ば，あとは緊張時の圧力一伸び直線の軌跡が示す $\mu$ の值 を統計量として管理して行くことができる。こてで再び 注意しなければならないてとは，てのようにして決めら

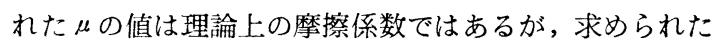
ルの值には見かけのヤング係数がばらつくととによる影 響がふくまれるため，もはや実際上の摩擦係数を示す值 ではなくなっている。したがって，ての值を $\mu^{\circ}$ であら わすことにする。図一24 はこれを示す一例である。

\section{図一24 摩擦試験から求めた $\mu$ と㗨張時の軌跡から 求めた $\mu^{\circ}$ の関係}

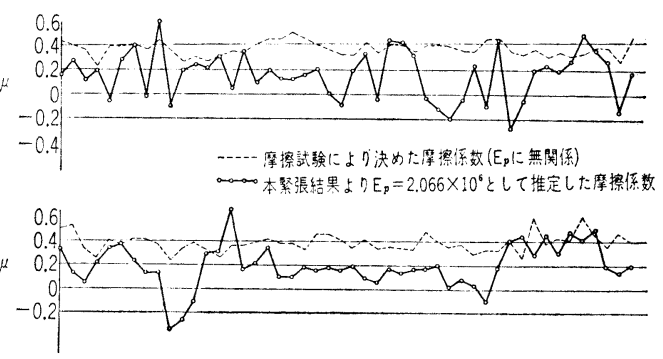

あるケーブルについて摩擦試験から求めた擦擦係数 とそのケーブルを緊張したときの圧力一伸び直線の軌跡 から求められた $\mu^{\circ}$ と関係をプロットしたものである が，ての両者はまったく相関がなくなっている。てれは $\check{E}_{p}$ のばらつきの影響の仕方が各ケーブルによって異な り，ての影響が大きく，両者の間の相関がまったく失な われてしまったものである。したがって, 統計量として ル゚を採用した場合, 個々のケーブルについては実際の 摩擦係数之はほとんど関係がないととを十分に心得てお く必要がある。

\section{(2) 統計量に関する実用上の検討}

a) 計算上の比較 2.において統計量として取り上げ た伸びから推定される引張力と荷重計から推定される引 張力の差 (てれを計算上の值に対する\%であらわす) $\delta$ と前節において提案した統計量 $\mu^{\circ}$ との間には，どの上 うな関係があるかを知っておくととが必要であろう。

図一22 から明らかなように $\mu^{\circ}$ は圧力一伸び直線の軌 跡と $\Delta l$ 軸または $P_{m}$ 軸との角度を表現をかえてあら わした值である。一方， $\delta$ の值については 図一25にお いて O-A を緊張計算において求めた圧力一伸び直線之 し, O-B が実際の緊張において得られた圧力一伸び直 線とすると，つぎのような関係がある。 
図 $25 \sigma, \Delta l$ と $\boldsymbol{\delta}$ との関係

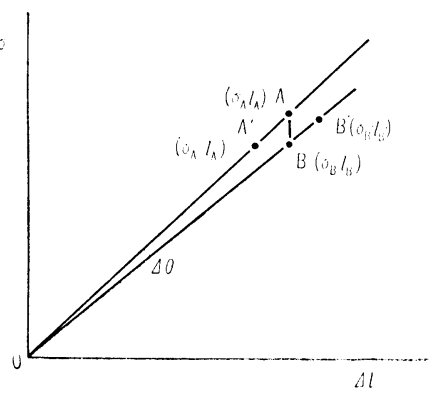

$\mathrm{A}^{\prime}$ 点とA䈍については，

$$
\delta_{A^{\prime}}=\frac{l_{A^{\prime}}-l_{A}}{l_{A}}-\frac{\sigma_{A^{\prime}}-\sigma_{A}}{\sigma_{A}}=\frac{l_{A^{\prime}}}{l_{A}}-\frac{\sigma_{A^{\prime}}}{\sigma_{A}}-0
$$

B 吕とA高については，

$$
\delta_{B}=\frac{l_{B}}{l_{A}}-\frac{\sigma_{B}}{\sigma_{A}}=1-\frac{\sigma_{B}}{\sigma_{A}}\left(\because l_{A}=l_{B}\right)
$$

$\mathrm{B}^{\prime}$ 悠とA器ついては,

$$
\delta_{B^{\prime}}=\frac{l_{B^{\prime}}}{l_{A}}-\frac{\sigma_{B^{\prime}}}{\sigma_{A}}=\frac{l_{B^{\prime}}}{l_{B}}\left(\frac{l_{B}}{l_{A}}-\frac{\sigma_{B}}{\sigma_{A}}\right)
$$

$\frac{l_{B^{\prime}}}{l_{B}}$ は央为上 1 と若えることができるので

$$
\doteqdot\left(\frac{l_{B}}{l_{A}}-\frac{\sigma_{B}}{\sigma_{A}}\right)=1-\frac{\sigma_{B}}{\sigma_{A}}
$$

すなわち， $\mathrm{OA}$ 㨁線と $\mathrm{OB}$ 直線の開きをあらわす侹 であるということができる。

このように理論的には統計䭪 $\mu^{\circ}$ と $\delta$ は，いずれも山” 才一伸び直線の勾配と近似的に一次の関係をあらわす数 值であり，互いの間にも近似的に一次の直線関係がなり 立たなけれはばならないはずである。

果たして, 実際上二つの統汁量の閪に淔線的な関係が 成立するか否かを調べるために，井出川橋の場合につい て各ケーブルの $\delta$ および $\mu^{\circ}$ の值の相関を求めてみると 図一26 のように明瞭な犆線の相関が得られる。
図一26 井出川 No. 1 No. 14 桁の 8 と $\mu^{\circ}$ の関係

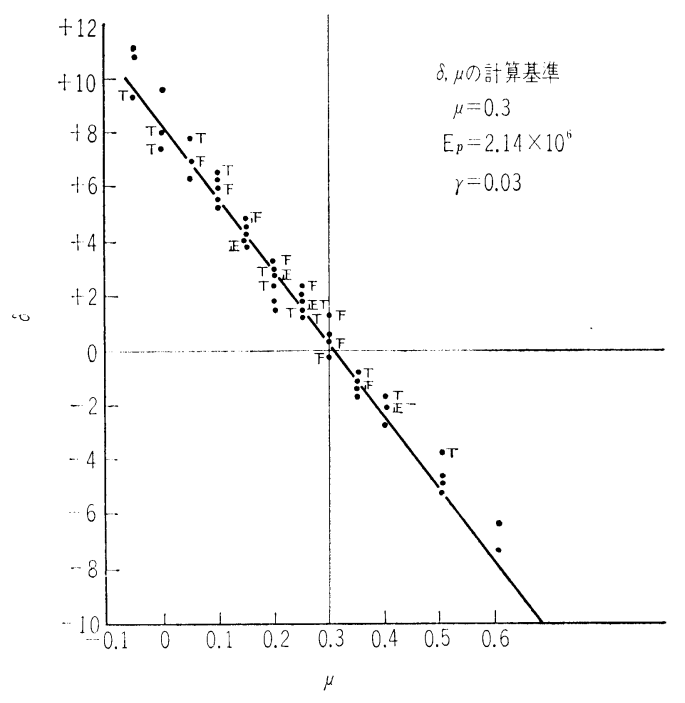

このことはプレストレッシングの管理の統部量として $\delta$ を採用しても，版を採用しても同等に管理が行なえ るであろうことを示すものである。

b）管理図の上における比較 a）において論じたよ うに二つの統計量 $\delta$ および $\mu^{\circ}$ は, 理論的にも, また夷 用上にも一次の関係があることが明らかになった。した がって，いずれの統計量によってプレストレッシングの 管理を行なっても同様の絬果が得られるであろうことを 想像することができる。しかし，図一26〜36でもわか るように耐者の間に直線の関係があっても, おのおのの 帒が完全に直線上にあるのではなく，ある程度のばらつ きを有している。したがって, 統計的管理という点から の央用性を確認するには同一の現場において行なった二 つの管理方法の管理図を比較してみなければならない。

図一27は森玔橋において行なった二つの管理广j法に

図一 278 法と $\mu^{\circ}$ 法による管理図の比較

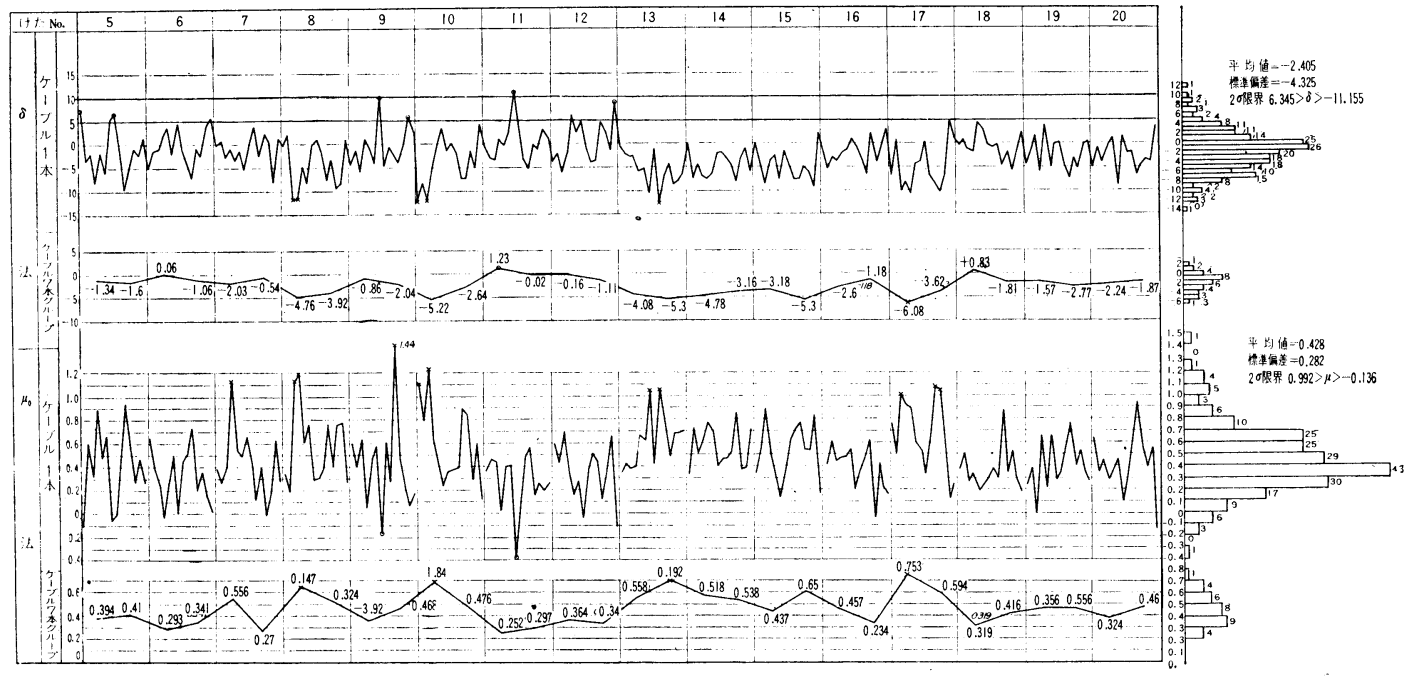




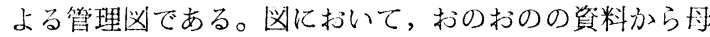
集团の平均値之標準偏差を推定し $2 \sigma$ をはずれるものを ○印または×卵で記してある。○印および×印は，どち らの側に $2 \sigma$ をはずれたかを示すものであり， $\delta$ 法にお ける大きい值は $\mu^{\circ}$ 法における小さい值に刘伈与ること を注意しておく必要がある。

てれによると個々のケーブルについては，20をはず れるものが一致していないものもあるが，傾问としてほ ぼ一致しているといえるであろう。また，ケーブル7本 を1グループにしたデータについてみると耐者一致して いるものは 1 カ所だけであるが，片方が $2 \sigma$ をはずれて いるものは，他もほとんど $2 \sigma$ の限界いっぱいにきて 打り，たまたまある值で線を引いたため管理限界をはず れるものが一致していないが，実用上の問題としては両 渚いず机よっても管理図の判定に大きな狂いを生ずる ことはないといい得るであろう。

$\delta$ 法によった場合, 伸びから推定される引陙力と街重 汁推定される引張力の間に標準偏差にして $5 \%$ のば らつきがあると考えており，ての值が一般的に実用して さし支えない值であるてとが確かめられている。法 によった場合， $\mu$ の值の標準偏差は一般的にいくらに考 光ればよいかという問題がおこってくる。いくつかの現 場において求めた $\mu^{\circ}$ の槽準偏差の推定值は 表一20 のよ うになる。てれ によると森户川 のように標準偏 差の推定値が, 表-20 $\mu$ の値の標準偏差の推定值

\begin{tabular}{|c|c|c|}
\hline 橋 梁 名 & 資料数 & 標準偏差の推定値 \\
\hline 小丸川 (前半) & 96 & 0.192 \\
\hline 小丸川（後半） & 96 & 0.143 \\
\hline 邦 出 川 & 100 & 0.144 \\
\hline 森戸川 & 224 & 0.282 \\
\hline 根＼cjkstart岸＼cjkstart線 & 576 & 0.175 \\
\hline
\end{tabular}
0.282 という大 きな值を示す例 もあるが，一般

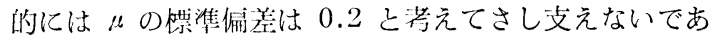
うう。

\section{8. 結論}

所要の強度, 酎久性, その他所要の性質を有する P C 部材を作るためにはコンクリートおよび $\mathrm{P} C$ 鋼材の品碩 の管理を行なわなければならないととはもちろんである がここれだけでは不十分であり，プレストレッシングの 管理を行なってはじめて所要の性質の P C 部材を作るこ そができるのである。

本研究はプレストレッシングの実用的な管理方法を明 らかにするため行なったものである。すなわち，P C 鉍道橋およそ 20 の工事現場について調查を行ない，調 查資料を整理した結果から得られた管理方法について畾 じたものである。一般にプレストレッシングの誤差はコ ンクリート抢よび P C 鋼材の品質, 測定器具の特性, お よび施工条件その他によって相違し, 非常に複雑なもの であり推計学的な考え方だけで取り挑うてとはできな
い。したがって，ブレストレッシングの管理法につい

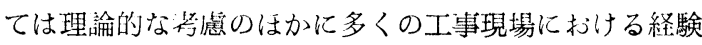
をも考慮することが必要となるのは当然である。

本研究における調査研究の笵囲では,つぎのことがい えると教えられる。

（1）プレストレッシングの䛊差の影響は P C 部材の 大きさそその他によって基なるが，プレストレッシング の詋差が数％にすざなくても一般にP C 部帆の安全性 亿無視し得ない影響を与えることが示された。例えば， 衍重計に $5 \%$ の狂いがあり，P C 銅材とシースの間の摩 擦係数が設部で答えたより 5 割多く，P C 鋼材のヤング 係数が設訃で考えた侹と $5 \%$ 違っていた場合，てれらを 哽虑しないでプレストレッシングを行なったとすると設 胡街重が載獄された場合，10％程度のプレストレスの 不足となり，てれによって，コンクリートには 15〜25 $\mathrm{kg} / \mathrm{cm}^{2}$ の予期しない引限応力を生じ P C 部材の安全度 は低下する。

荷重訃，P C 鐥材とシースの間の摩摖係数，P C 鋼材 のヤング係数などの留差が抢よぼす泪影響は P C 部材の スパンが長くなり，自重の占些合が大きくなるほど いちじるしくなるのであるから，長大スパンのP C 橋梁 においては特に，䛊差の影響を少なくするよう将虑する ととが大切である。

（2）実際のプレストレッシングの作業においてP C

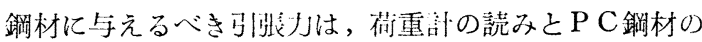
伸びの測定值とから定りている。しかし，一般倠重計 の読みと伸びの测定偡との間には緊张計算において求妨 たこれらの関係と相当に異なった関係を生じる場合が少 なくない。例えば，街重計に狂いがなく P C 鋼材とシー スの間の摩摖係数，P C 鋼材のヤング係数などにほとん ど誤差が惁められないのに荷重計の読みと伸びの測定值 との間に $10 \%$ 程度の差を生じることは珍しくないので あって，20\% 以上の差を生じるととすらある。二つの 测定値の間にてのように大きな差を生じる原因その他に ついて調查した絬果，橋梁において広く使用される P C ケーブルにおいては二つの測定做の間に䌘準偏差にして $5 \%$ 程度のばらつきを生じ，しかも，この值は管理状態 の良好な工事現場においても间程度であるてとが明らか にされた。とのようなばらつきがあるため，佃々のP C ケーブルについて，いかに入念なプレストレッシングの 管理を行なっても P C 部材としては不十分なプレストレ ッシングの管理しか行なうととができない。偶然誤差に よる影響を少なくし，人為的な䛊差をただちに発見して 早期に必要な処置をとるためには P C ケーブルを組に分 け，各組の平均值にもとづいて管理するのが適当な方法 であることが明らかにされた。しかし，組に分けて行な う管理の效果をいっそう有郊に与るたりには各組におけ るばらつきが闭一の呌隼期となるように溚虑する必要が 
ある。すなわち, 配置形状の異なる P Cケーブルが各組 に均等に分けられるように組分けすることが必要である (土木学会論文集第 76 号)。

（3）従来, P C 鋼材の伸びの計算には P C 鋼材の引 張試験の際の応力一ひずみ曲線から求められたヤング係 数を用いるべきであるとされてきた。そして，てれによ って実用上，十分正確な值が得られるものと考えられて きた。しかし，多くの工事現場において調査した結果， シース内に配置された P C ケーブルの伸び量から逆算し たヤング係数は引張試験の結果から求められたヤング係 数より，一般に小さな值となることが示された。例え ば, 引張試験から求めたヤング係数が $2.05 \times 10^{6} \mathrm{~kg} / \mathrm{cm}^{2}$ 程度であるのにこの P C 鋼材を実際に緊張してみると $1.95 \times 10^{6} \mathrm{~kg} / \mathrm{cm}^{2}$ 程度の值となり，個々のケーブルにつ いては $1.80 \times 10^{6} \mathrm{~kg} / \mathrm{cm}^{2}$ 以下の值になることもあった。 ての原因としては，PCヶーブルの曲がりによる縁ひず みが付加されること, 応力一ひずみ曲線の比例限界を越 える引張応力を与えること，P C 部材の弾性縮みを考虑 しないでP C 鋼材の抜け出し量を伸び量とするととなど が考えられる。しかし，てれらの原因だけでは前記のよ うないちじるしい差を生ずるととは説明できないのであ る。工事現場における諸調査を検討した結果，センター スパイラルの弾性変形, センタースパイラルの外周に そって P C 鋼材が移動することなどによって, プレスト レッシングの作業中に P C ケーブルが鉛直に移動し, $\mathrm{P}$ Cヶーブルの端部において，伸びの増加となってあらわ れることが大きな原因になり得ることが示された。した がって, P Cケーブルの伸びの計算には P C 鋼材の引張 試験の際の応力一ひずみ曲線から求めたヤング係数のか わりに, 実際のPCケーブルについてあらかじめ緊張試 験を行ない，てれから求められたPCケーブルの見かけ のヤング係数を用いる必要があるのである。

(4) P C 鋼材とシースの間の摩擦係数は P C 鋼材の 単位長さあたりの摩擦損失係数 $\lambda$ と P C 鋼材の単位角 変化あたりの摩擦損失係数 行なわれている。1本のPCケーブルに二つの変数があ るため, PCケーブルの摩擦係数を求める場合, 何本か のPCケーブルについて摩摖試験を行ない，乙の結果か ら最小自乗法によって平均的な $\mu$ および $\lambda$ の值を求め ていたのである。このようにすれば個々のPCケーブル の $\mu$ および入を知ることはできないてとになり,プレ ストレッシングの作業に不便な点があらわれてくる。調 査の結果によると $\lambda i \mu$ の值は 0.005 から 0.03 の範囲 で変動していたが, この変動がプレストレッシングの管 理におよぼす影響は無視してもさし支えないてとが示さ れた。したがって，P C 鋼材とシースの間の摩摖係数は $\mu$ のみの関数とし, $\lambda / \mu$ の值を 0.015 程度の一定の值 と考えるのが実用上便利であると思われる。
（5）プレストレッシングの管理を行なう場合，基準 とする統計量の選定が重要な問題である。プレストレッ シングの作業において，われわれが直接知りうる值は $\mathrm{P}$ $\mathrm{C}$ 鋼材の伸び量と P C 鋼材の端部の引張力を示す荷重計 の読みの二つである。多くの現場における調查の結果か ら, 伸びから推定される引張力と荷重計の読みから推定 される引張力との差を統計量に選ぶことによって, 実用 的なプレストレッシングの管理が行なえることが示され た。なお，さらに検討を続けた結果，プレストレッシン グの際の P C 鋼材とシースの間の見かけの摩擦係数を緊 張図の上から求め，てれを統計量として管理すれば管理 を簡単化するととができ，しかも，PCケーブルの引き 止め点を合理的に決めることができる。しかも，管理の 効果は伸びから推定される引張力と荷重計から推定され る引張力の差を統計量に選ぶ場合と実用的には同様であ るととが示された。

これを要するにプレストレッシングの管理にあたって は，P C 鋼材の見かけのヤング係数， P C 鋼材とシース の間の摩擦係数を正確に把握することも大切であるが, P Cケーブルを適当な組に分け，各組でとに管理を行な うことがもっとも大切であると思われる。

\section{参 考文 献}

1）川口・和仁・菅原・野口・羽田野 : 小丸川 P C 鉄道橋の 架替え工事ならびに関連して行なった 実験的研究報告, 土木学会論文集第 76 号, 1961年 9 月.

2）野口 功：プレストレッシングの管理について, 昭和 36 年土木学会夏期講習会, “最近におけるプレストレスト コンクリート".

3）丸安隆和：エンクリートの品質管理, 土木学会刊行, 1956 年 11 月.

4）仁杉 厳：支間 $30 \mathrm{~m}$ のプレストレストコンクリート鉄 道橋 (信楽線第一大戸川橋梁) の設計・施工およびこれ に関連して行なった実験研究の報告, 土木学会論文集第 27 号, 1950 年 7 月.

5）斎藤 昇: プレストレッシング管理のための一考察, 土 木技術 18 巻 1 号, 1963 年 1 月, 2 月.

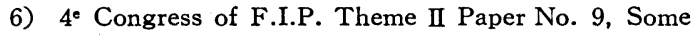
problem in prestressed concrete construction in Japan.

7）野口 功・斎藤 昇: プレストレッシングに関する一考 察(ケーブルのグループ分けについての検討), プレストレ ストコンクリート技術協会 第 3 回年次学術講演会, 1963 年 2 月 11 日.

8）野口 功：プレストレッシングの管理，プレストレスト コンクリート, 1963 年 2 月.

9) 森口繁一: 初等数理統計学.

10）高 金地: 統計的品質管理の基礎.

11）W.A. シュハート（坂本平入訳）：品質管理の基礎概念.

12）西堀栄三郎・磯部邦夫 : 品質管理実施法.

13) Barets, J. : Dispersion et controle des allongements dans les operations de précontrainte, Association Scientifique de la Précontrainte, 1 er session d'étude novembre 1956.

14) Dumas, F. : Résistance et sécurité du béton précontraint, Travaux, novembre, décembre 1958. janvier, février, mai, novembre, décembre 1959. janvier, mars, octobre, 19601961. 
15) Rǒs, R. : Steel wire for prestressed concrete considered from the point of view of the designer, Rapport Final Symposium de la R.I.L.E.M. juillet, 1958.

16) ACI-ASCE Joint Commitee, Tentative recommendations for prestressed concrete, 1957.

17) S.N.C.F. : Cahier des charges specials ouvrage en béton précontraint, 4 mars, 1959.

19) Cooley, E.H. : Friction in post-tensioned prestressing systems, Cement and Concrete Association Research Report 1, 1953, october.

20) Ministère des Travaux Publics : Instructions relatives à l'emploi du béton précontraint, 1953.

（原楀受付 : 1963.6.25）

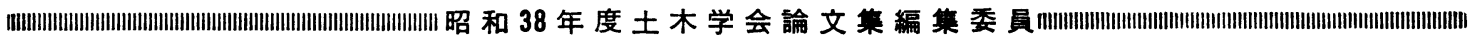

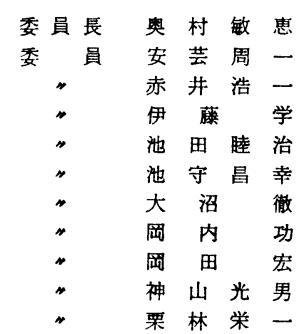

\begin{tabular}{|c|c|c|c|}
\hline 副委員長 & 吉 & 川 & 秀 \\
\hline 委 員 & 小 & 池 & \\
\hline " & 小 & 寺 & 重 \\
\hline$"$ & 後 & 藤 & 圭 \\
\hline " & 佐 & 武 & 正 \\
\hline$"$ & 佐 & 藤 & 昭 \\
\hline$"$ & 杉 & 木 & 昭 \\
\hline$\Rightarrow$ & 鈴 & 木 & 婎 \\
\hline " & 多 & 田 & 宏 \\
\hline$"$ & 建 & 部 & 恒 \\
\hline$"$ & 玉 & 野 & 治 \\
\hline
\end{tabular}

\begin{tabular}{|c|c|}
\hline 員 & 土 肥 正 \\
\hline " & 中川 博 \\
\hline$"$ & 中＼cjkstart瀬 \\
\hline " & 伯＼cjkstart野 \\
\hline$"$ & 林 \\
\hline$"$ & 久 武 罟 \\
\hline$"$ & 藤 由 嘉 \\
\hline$"$ & 堀井健一 \\
\hline " & 堀 川清 \\
\hline$"$ & 尾 元 \\
\hline
\end{tabular}

委虽三木五三郎

" 村上良丸

" 村田二郎

" 八木田功

" 山 根孟

" 箭内宽 治

" 山䗁徳也

" 吉田粦

幹事西脇威 夫

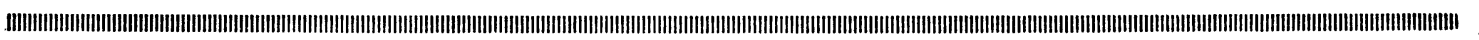

昭和 39 年 2 月 15 日印刷 昭和 39 年 2 月 20 日 発 行

\section{土木学会論交集 第 102 号定価 150 円（广 20 円）}

編集兼発行者東京都新宿区四谷一丁目社団法人 土木学会羽田䏼 印刷 者東京都港区赤坂溜池 5 株式会社技報堂大沼 正吉

\section{発行所 社界 土 木 学 会 振替東京 16828 番}

東京都新宿郵便局区内 新 宿区四谷一丁目電話 (351) 代表 5138 番 